\title{
A los cultos umbrales del Museo: la écfrasis en el Paraíso cerrado de Pedro Soto de Rojas ${ }^{1}$
}

\author{
Jesús Ponce Cárdenas \\ Universidad Complutense de Madrid
}

Título: A los cultos umbrales del Museo: la écfrasis en el Paraíso cerrado de Pedro Soto de Rojas.

Resumen: El presente estudio analiza la descripción de varios cuadros que Pedro Soto de Rojas engastó en la topografía de la mansión sexta del Paraiso cerrado para muchos, jardines abiertos para pocos. El artículo reflexiona asimismo sobre el alcance de la écfrasis en la poesía descriptiva de villas, palacios y jardines y sobre el coleccionismo en el medio urbano de la Andalucía barroca.

Palabras clave: Écfrasis, Soto de Rojas, poesía descriptiva de villas, palacios y jardines.

Fecha de recepción: 20/4/2021.

Fecha de aceptación: 23/6/2021.
Title: Before the Cult Threshold of the Museum: Ekphrasis in Pedro Soto de Rojas' Paraíso cerrado.

Abstract: This study analyses the poetic description of several paintings from the Pedro Soto de Rojas' Collection, located in the sixth mansion of the Paradise closed. The article also raises a reflection on the ekphrasis in the Country-House Poems and collecting in baroque Andalusia.

Key words: Ekphrasis, Soto de Rojas, Country House Poem.

Date of Receipt: 20/4/2021.

Date of Approval: 23/6/2021.

1 Este artículo forma parte del Proyecto "Hibridismo y Elogio en la España áurea» (HELEA), PGC2018-095206-B-I00, financiado por el Ministerio de Ciencia, Innovación y Universidades y por el Fondo Europeo de Desarrollo Regional. Quisiera agradecer a Mercedes Blanco, Pedro Conde Parrado, Juan Matas Caballero y Ángel Rivas Albaladejo la generosa lectura del original de este ensayo, así como los consejos y anotaciones que me han brindado para mejorarlo. Quisiera hacer extensivo mi agradecimiento a los dos informantes anónimos que han leído con atención estas páginas y me han proporcionado útiles observaciones con toda cortesía. 
La poesía descriptiva de villas, palacios, jardines y espacios sacros se desarrolló como género en España, aproximadamente, entre 1580 y 1660. Diversos autores cultivaron esta modalidad de escritura laudatoria, imbuida de valores plásticos, durante los reinados de Felipe II, Felipe III y Felipe IV. Entre los mismos figuran escritores de primer orden como Lupercio Leonardo de Argensola, Lope de Vega, Francisco de Quevedo o Pedro Soto de Rojas. También elaboraron este tipo de encomios algunos ingenios menores, como Baltasar Elisio de Medinilla, el conde de Rebolledo, Juan Silvestre Gómez, Manoel de Galhegos, José Pellicer de Salas, Andrés de Ustarroz, Manuel de Faria e Sousa... La tipología edilicia ensalzada en sus versos resulta amplia y variada, así como el perfil de los propietarios de aquellas moradas y jardines monumentales: reales sitios (Aranjuez), jardines de claustros monásticos (Aula Dei), residencias veraniegas del monarca (Hirscholm), palacios aristocráticos circundados de soberbios parques y huertas (Abadía, la casa jardín de los condes de Monterrey), quintas de las más altas jerarquías eclesiásticas (el cigarral de Bellavista) o, incluso, residencias privadas ubicadas en un entorno urbano (el carmen de los Mascarones, la mansión oscense de Lastanosa) ${ }^{2}$.

Dentro del catálogo de composiciones adscritas al género descriptivo de villas, palacios y jardines, el Paraiso cerrado para muchos, jardín abierto para pocos ocupa un lugar especial por varias razones. La primera de ellas es su nombradía misma, ya que esta obra, salida de los tórculos de la Imprenta Real de Granada en 1652, constituye sin duda el espécimen más famoso de esta modalidad laudatoria. En efecto, la silva que Pedro Soto de Rojas consagró a su propia residencia en el Albaicín y a los suntuosos jardines que la adornaban ha gozado de gran reconocimiento

2 Como sucinta presentación del género descriptivo-laudatorio, puede verse la reciente monografía de Jesús Ponce Cárdenas y Ángel Rivas Albaladejo, El jardín del conde de Monterrey. Arte, Naturaleza y Panegírico, Salamanca, Delirio, 2018, pp. 119-166. Cabe remitir, asimismo, a la tesis doctoral que actualmente desarrolla Alberto Fadón Duarte bajo mi dirección: Palacios, jardines y espacios sacros en la poesía áurea: historia, forma y función de un género laudatorio (1580-1700). Del mismo estudioso puede verse la contribución en este monográfico ("Perfiles del coleccionismo barroco: Andrés de Ustarroz y la Descripción de las antigüedades y jardines de don Vincencio Juan de Lastanosa"), así como su artículo sobre la descripción en verso del palacio danés de Hirscholme a la luz del modelo de Góngora: "La verde pompa y la generosa cetrería: claves gongorinas en la segunda Selva dánica”, Studia Aurea, 15 (2021), pp. 163-192. 
desde el momento de su aparición hasta nuestros días. Merced a la labor desarrollada por estudiosos como Emilio Orozco Díaz, Antonio Gallego Morell, Federico Bermúdez Cañete, Elsa Dehennin, Luis Gómez Canseco, José Fernández Dougnac, Aurora Egido, José Lara Garrido, Alan S. Trueblood, Andrés Soria Olmedo, Rubén Pardo, Ana María García o Dominique de Courcelles, se han ido esclareciendo algunos aspectos clave de esta composición ${ }^{3}$. Tales aportaciones han arrojado luz sobre diferentes

3 Emilio Orozco Díaz, Introducción a un poema barroco granadino (De las Soledades gongorinas al Paraíso de Soto de Rojas), Granada, Universidad de Granada, 1955. El ensayo aparece recogido, con algunas ampliaciones, en Paisaje y sentimiento de la naturaleza en la poesía espańola, ed. José Lara Garrido, Málaga, Universidad de Málaga, 2010, pp. 139-228; Antonio Gallego Morell, "Pedro Soto de Rojas", Estudios sobre poesía española del primer Siglo de Oro, Madrid, Ínsula, 1970, pp. 119183; Federico Bermúdez Cañete, "Notas sobre la naturaleza en Soto de Rojas", Cuadernos Hispanoamericanos, 412 (1984), pp. 110-121; Elsa Dehennin, "Poesía culterana: Góngora frente a Soto de Rojas", Edad de Oro, 6 (1987), pp. 67-77; Luis Gómez Canseco, "Individualidad y religión en el Paraíso cerrado de Pedro Soto de Rojas", Philologia Hispalensis, 4, 1 (1989), pp. 355-363; José Fernández Dougnac, El Paraíso comentado. Estudio, edición y versión en prosa del Paraíso cerrado de Pedro Soto de Rojas, Granada, Ediciones Antonio Ubago, 1992; Aurora Egido, "Estudio introductorio" a su edición de Pedro Soto de Rojas, Paraíso cerrado para muchos, jardines abiertos para pocos. Los fragmentos de Adonis, Madrid, Cátedra, 1993², pp. 22-46; Alan S. Trueblood, "A Reading of the Parayso of Soto de Rojas", Caliope, II, 2 (1996), pp. 5-29; José Lara Garrido, "De la ejemplaridad petrarquista al gongorismo esencializado en Pedro Soto de Rojas", en Del Siglo de Oro (métodos y relecciones), Madrid, Universidad Europea/CEES, 1997, pp. 215-222; Andrés Soria Olmedo, "Jardines de palabras (entre Guillén y Soto)", en Sin fronteras. Ensayos de Literatura Comparada en homenaje a Claudio Guillén, eds. Darío Villanueva, Antonio Monegal y Enric Bou, Madrid, Castalia, 1999, pp. 89-103. Este trabajo aparece también recogido en Andrés Soria Olmedo, Siete estudios sobre la Edad de Oro, Granada, Editorial Alhulia, 2008, pp. 84-107; Rubén Pardo Lesta, "Del mundo simbólico al mundo poético: el Paraíso cerrado de Pedro Soto de Rojas como ejemplo de poema emblemático", en Del libro de emblemas a la ciudad simbólica. Actas del III Simposio Internacional de Emblemática Hispánica, ed. Víctor Mínguez, Castellón, Universitat Jaume I, 2000, II, pp. 1009-1036; Aurora Egido, Jardines hechos y deshechos: Lope de Vega, Soto de Rojas y Baltasar Gracián, Santa María del Cayón, Ayuntamiento de Santa María del Cayón, 2013; Ana María García Martín, La mitología en el Paraíso cerrado de Pedro Soto de Rojas, Don Benito, Edita, 2016; y Dominique de Courcelles, Habitar maravillosamente el mundo. Jardines, palacios y moradas espirituales en la España de los siglos XV al XVII, Madrid, Siruela, 2020, pp. 74-82. 
aspectos esenciales en el complejo poema barroco: la visión de la naturaleza que preside sus versos y la relevancia de los efectos pictóricos, la exaltación del jardín andalusí, los valores religiosos y espirituales que dimanan de algunos fragmentos, la conexión con los emblemas, la imitación del estilo culto y obscuro instaurado por Góngora en las obras mayores... El segundo rasgo que enfatiza la singularidad del Paraíso cerrado es que en la figura de Pedro Soto de Rojas confluyen dos perfiles: el del propietario y artífice que concibió y mandó edificar el jardín y el del poeta que, una vez construido el hortus conclusus, aspira a eternizar con sus versos un enclave donde naturaleza y arte se funden. Por último, el tercer elemento que se ha de considerar es la obscuridad misma del poema, considerado - no en vano- una de las cimas de la lírica culta barroca por su complejidad.

Pese al avance cualitativo que ha supuesto el caudal de trabajos aludido anteriormente, la obra de Pedro Soto de Rojas guarda aún varios aspectos que deben ser elucidados. La intención de este artículo es iluminar uno de esos detalles, poniendo el foco en la función y relevancia que asume la écfrasis de una serie de cuadros que pertenecieron a la colección privada del escritor. Con esa finalidad la reflexión se organizará en cuatro bloques: en el primero se pasa revista a un conjunto de transposiciones artísticas insertas en el género de la poesía descriptiva, desde sus orígenes hasta el siglo XVII; en la segunda sección se examinan las notas de Trillo y Figueroa al poema de Soto de Rojas, con el propósito de aclarar cuál pudo ser el aspecto real del paraje evocado; el tercer apartado se reserva para el análisis del pasaje de la Mansión sexta dedicado a la descripción de las pinturas y, finalmente, a modo de conclusión, el cuarto bloque trata de calibrar la relevancia de esta pequeña colección de obras artísticas en su contexto geográfico y socio-cultural.

\section{UARIAS UBI PICTA PER ARTES: transposición artística y POESIE DI VILLA}

Concebida para ensalzar las moradas suntuosas de las clases aristocráticas, el origen de la poesía descriptiva de villas se remonta hasta la Edad de Plata latina, ya que fue Estacio quien marcó a fuego los parámetros del nuevo género con dos Silvas destinadas a erigirse en modelos aptos para la imitación a partir del Quattrocento. Los textos primigenios que sentaron 
las bases del poema jardin (o poesie di villa) fueron la silva I, 3 Villa Tiburtina Manili Vopisci (A la villa de Publio Manilio Vopisco en Tivoli) y la silva II, 2 Villa Surrentina Polli Felicis (A la villa de Polio Félix en Sorrento). Por cuanto se refiere al plano de la dispositio, las composiciones a la villa tiburtina y a la villa surrentina obedecen a un mismo esquema retórico, tan simple como eficaz ${ }^{4}$. En sendas pinturas verbales se acomete una descripción detallada de las respectivas residencias de recreo de dos nobles patricios: salones, habitaciones con vistas, baños termales, pórticos. Los versos se detienen en la ubicación geográfica y la pintura del enclave natural privilegiado y se cierran con la enumeración de las piezas artísticas, los ornamentos parietales o musivarios, así como el rico mobiliario que ornan estas suntuosas moradas, configurando de tal modo una suerte de focalización progresiva. Así pues los senderos afines de la topografía (descriptio loci) y la écfrasis (descriptio artis) confluyen, para formar una armoniosa mixtura con el encomio del acaudalado mecenas. La alabanza del lugar y de los objetos artísticos configura, por ende, "powerful statements and symbols of the ethical, intellectual and social position of the owners"s. La villa marina de Sorrento y la villa de interior de Tíbur representan dos tipos de enclave de imponderable belleza natural, perfeccionados por el ingenio y el arte .

4 Carole Newlands, "Imperial Pastoral: Vopiscus' Villa in Silvae I, 3" y "Dominating nature: Pollius' Villa in Silvae, II, 2", capítulos IV y V de la monografía Statius' Silvae and the Poetics of Empire, Cambridge, Cambridge University Press, 2004, pp. 119-198.

5 K. Sara Myers, "Docta otia: Garden Ownership and Configurations of Leisure in Statius and Pliny the Younger", Arethusa, 38, 1 (2005), pp. 103-129 (pp. 105-106).

6 La descripción de obras de arte ocupa un lugar nada desdeñable en ambas composiciones. La silva I, 3 se centra en esculturas y mosaicos (vv. 47-57): "Vidi artes veterumque manus variisque metalla / viva modis. Labor est auri memorare figuras / aut ebur aut dignas digitis contingere gemmas, / quicquid et argento primum vel in aere minori / lusit et enormes manus expertura colossos. / Dum vagor aspectu visusque per omnia duco / calcabam necopinus opes. Nam splendor ab alto / defluus et nitidum referentes aëra testae / monstrauere solum, uarias ubi picta per artes / gaudet humus superatque nouis asarota figuris. / Expauere gradus" ("Vi obras de arte, creaciones de maestros antiguos, metales vivientes en varios modos. Resulta trabajoso dar cuenta de las figuras de oro o el marfil o las gemas dignas de ornar los dedos o todo aquello que concibió en su imaginación el artista y primero plasmó en miniatura en plata o en bronce, para luego modelar enormes colosos. Mientras erraba absorto y recorría todo con la vista, 
El regreso a los modelos clásicos impulsado por el Humanismo renovó el interés por los géneros del elogio, entre los cuales cabe situar la poesia di villa. Desde el siglo XV comenzó, por tanto, a cultivarse en Italia la composición de poemas descriptivos consagrados a villas y jardines, tanto en latín humanístico (Battista Spagnoli, Egidio Gallo, Francesco Speroli, Marco Girolamo Vida, Lorenzo Gambara, Aurelio Orsi, Giovanni Antonio Liberati...) como en italiano (Luigi Tansillo, Pietro Andrea Mattioli, Veronica Franco, Raffaello Gualterotti, Gabriello Chiabrera, Giovan Vincenzo Imperiale, Fulvio Testi, Lodovico Adimari...) $)^{7}$.

advertí de repente la riqueza que pisaba. En efecto, la radiante luz que se vertía desde lo alto y las tejas que reflejaban el luminoso ambiente me mostraron el brillante suelo, donde la tierra se regocijaba con la variedad de las pinturas y con las nuevas figuras que supera el trampantojo del suelo sin barrer. Mis pasos se detuvieron asombrados"). La silva II, 2 habla de pinturas y estatuas de bronce (vv. 63-72): "Quid referam veteres ceraeque aeris figuras / si quid Apellei gaudent animasse colores, / si quid adhuc vacua tamen admirabile Pisa / Phidiacae rasere manus, quod ab arte Myronis / aut Polycliteo iussum est quod vivere caelo, / aeraque ab Isthmiacis auro potiora favillis, / ora ducum ac vatum sapientumque ora priorum, / quos tibi cura sequi, quos toto pectore sentis / expers curarum atque animum virtute quieta / compositus semperque tuus?” "¿Qué diré de las antiguas figuras pintadas al encausto o cinceladas en bronce, formas que se regocijan de la vida otorgada por los colores de Apeles, formas modeladas por las manos de Fidias — obra admirable, aun cuando Pisa estaba despoblada todavía - o las que el arte de Mirón o de Policleto trajo a la vida, los bronces que surgieron de las cenizas ístmicas, más preciosos que el oro, los bustos de caudillos y poetas, y los bustos de los sabios del pasado, aquellos a los que te esfuerzas en seguir, a los que sientes por entero en tu corazón, carente de inquietudes en tu serena virtud, siempre dueño de ti mismo"). Las citas proceden de Statius, Silvae, ed. y trad. Shackleton Bailey, Cambridge/ London, Harvard University Press, 2003, pp. 64-66 y 126-128.

7 Se puede ampliar la información sobre fuentes clásicas, neolatinas e italianas de este tipo de composiciones descriptivas en Ponce Cárdenas y Rivas Albaladejo, op. cit., pp. 128-155. Sobre el ámbito italiano en general, véase Carlo Caruso, "Poesia umanistica di villa", en Feconde venner le carte. Studi in onore di Ottavio Besomi, ed. Tatiana Crivelli, Bellinzona, Edizioni Casagrande, 1997, pp. 272-294. Para la región de Nápoles, remito a los estudios de Carlos José Hernando Sánchez: "Los jardines de Nápoles en el siglo XVI. Naturaleza y poder en la corte virreinal", en Jardin y Naturaleza en el reinado de Felipe II, eds. Carmen Añón y José Luis Sancho, Madrid, Sociedad Estatal para la Conmemoración de los Centenarios de Felipe II y Carlos V, 1998, pp. 139153; y "La cultura de la villa entre Nápoles y Espańa: los jardines de los Toledo en el siglo XVI", en AA. VV., Dimore signorili a Napoli. Palazzo Zevallos Stigliano e il mecenatismo aristocratico dal XVI al XX secolo, Napoli, Intesa San Paolo, 2013, pp. 11-48. 
Siguiendo la horma del dechado estaciano, en esa doble tradición italiana y neolatina, las poesie di villa no solo abordaron la descripción de lujosas moradas campestres y villas suburbanas de nobles, banqueros y prelados, ni se limitaron a pintar verbalmente los jardines que las ornaban. Junto al ejercicio de topografía, los poetas también dedicaron versos memorables a la transposición de arte, ya que igualmente exaltaron las galerías de cuadros que formaban parte de aquellas residencias regias o aristocráticas, así como las pinturas al fresco que adornaban algunas de sus salas principales. Baste citar, por ahora, cuatro ejemplos conspicuos de la Hesperia Magna. En primer lugar, Pietro Andrea Mattioli en Il Magno Palazzo del cardinale di Trento (Venezia, Francesco Marcolini, 1539) ensalza las pinturas mitológicas que adornan la residencia del jerarca eclesiástico ${ }^{8}$. En el marco laudatorio de la Arcis Caprarolae Descriptio, Lorenzo Gambara en 1569 fijó su atención en los frescos de la Sala della Solitudine y la Sala della Penitenza, con imágenes de tema sacro realizadas por Federico y Taddeo Zuccari (Laurentii Gambare Brixiani Poemata, Antuerpia, Officina Christopohori Plantini, 1569). Por su parte, en los albores del Barroco, el hijo del Doge de Génova, Giovan Vincenzo Imperiale, evocaría las pinturas parietales de Bernardo Castello (David da muerte a Goliath, Judith y Holofernes, David y el león) que adornaban la residencia de su familia: la Villa Imperiale in Sampierdarena (Lo Stato Rustico, con ediciones en 1607, 1611 y 1613). Finalmente, Lodovico Adimari exaltaba, al culminar el siglo, los tesoros artísticos (pinturas y esculturas) que el Rey Sol había reunido en el palacio de Versalles (Glorie di Lodovico XIV il Grande nelle Delizie di Versaglie, 1693)'.

8 Recuérdese cómo en el siglo XVI el cardenal Bernardo di Cles ordenó la ampliación del Castello del Buon Consiglio, edificando consiguientemente la sección renacentista de la morada arzobispal conocida desde entonces como Magno Palazzo. Destacó en la misma el conjunto de frescos de Dosso Dossi, Romanino y Battista Dossi, que reflejan varios episodios de la historia antigua y de los mitos clásicos.

$9 \mathrm{Al}$ tratarse de la composición acaso menos conocida hoy, reproduzco seguidamente las estancias que Lodovico Adimari dedicó a la sucinta evocación de los artistas que figuran como principales autores dentro de la Colección Real. Como pintores destacan Parmigianino, Veronese, Tintoretto, Bassano, los Carracci, Rafael, Guercino, Pietro da Cortona, Andrea Mantegna. En el campo de la escultura se pondera, sobre todo, a Miguel Ángel y a Bernini. Las octavas de Adimari rezan así: "Pendono in varie parti e in varie tele / d'altri artefici illustri i bei sudori, / il cui nome immortal 
Si pasamos del ámbito italiano al hispánico, la asociación entre el poema descriptivo de palacios y jardines y la écfrasis, ya de cuadros, ya de pinturas parietales, se advierte en varios textos de singular interés. Me limitaré a nombrar aquí dos ejemplos: las Selvas dánicas del conde Bernardino de Rebolledo y la Silva topográfica al Buen Retiro de Manoel de Galhegos. En efecto, en la segunda Selva dánica, titulada Hirscholme, el embajador de Felipe IV ante la corte de Copenhague exalta los lienzos y frescos de Karel Van Mander que ornaban la residencia veraniega de la reina Sofía Amalia de Luneburg ${ }^{10}$. De manera afín, en la Silva topográfica al Buen Retiro, publicada por Manoel de Galhegos en 1637, encontramos la écfrasis de los retratos de la familia real exhibidos en el Salón de Reinos así como varias transposiciones de arte referidas a lienzos de Rubens, Velázquez, Snyders o Guido Reni ${ }^{11}$.

non fia, ch'io cele / per involargli ai meritati onori; / par che Guido famoso in lor si svele, / chiaro autor di portenti e di stupori, / e con esso quei due, di cui ragiona / con rimbombo gentil Parma e Verona. / Scopron de l'arte i pregi i più sublimi / che ne l'arte medesma ebber gran vanto: / Tintoretto e Bassan sorgon fra i primi / coi tre Caracci e Raffaello a canto, / vanno i due Pietri di gran luce opimi / con quel da Cento e più lontano alquanto / mostra ne l'opre sue ciò che potea / Toscan disegno il portentoso Andrea. / Le Loggie anch'esse a le pitture a fronte / di non volgar scalpel s'ornan coi pregi, / chiudendo in sen le più famose e conte / statue condotte da Maestri egregi. / Dia Carrara i suoi marmi o il Pario monte, / esprima il simolacro uomini o regi, / nulla ciò cal, pur che ne sia l'autore / Fidia col braccio o col cisel Mentore. / Sfida le glorie antiche il peregrino / scolpir che illustra a noi l'età presente, / e il Buonarroti sol, men che divino, / perch'è mortal, d'ogni altro appar vincente, / l'onor dei Belgi e il singolar Bernino / del par trionfa o non riman perdente; / nei diversi lavori il ver si scopre, / e il Gran Versaglie è paragon de l'opre" (Glorie di Lodovico XIV il Grande nelle Delizie di Versaglie, en el volumen epidíctico Poesie di Lodovico Adimari, patrizio fiorentino e gentiluomo della camera del Serenissimo di Mantova alla Maestà del Gloriosissimo e Cristianissimo Re Lodovico XIV il Grande, s.l., s.e., 1693). El volumen carece de numeración de páginas.

10 Para comprender algunos matices en la evocación de los paisajes cetreros que podían contemplarse en el palacio danés es útil la consulta de dos trabajos recientes: Jesús Ponce Cárdenas, "La imitación del discurso gongorino de la cetrería: primeras calas", en Los géneros poéticos del Siglo de Oro. Centros y periferias, eds. Rodrigo Cacho y Anne Holloway, Woodbridge, Tamesis, 2013, pp. 171-194; y Fadón Duarte, "La verde pompa y la generosa cetrería".

11 Sobre el texto del poeta luso, permítase remitir al reciente estudio de Jesús Ponce Cárdenas, "Pintura y Panegírico: usos de la écfrasis en Manoel de Galhegos", Versants, 65, 3 (2018), pp. 97-123. 
Al cotejarlo con los poemas aludidos, el caso del Paraíso cerrado presenta algún contorno peculiar, ya que en la silva no se evoca la fastuosa colección pictórica de un soberano (el Buen Retiro, Versalles), ni los cuadros o las pinturas murales que pueden admirarse en el palacio de un prelado de la Italia septentrional (el cardenal de Trento), en la residencia campestre de los herederos del papa Paulo III (Villa Farnese a Caprarola) o en la de un acaudalado aristócrata genovés (Villa Imperiale in Sampierdarena). La composición de Soto se mueve en un entorno artístico mucho más limitado, ya que el pasaje de la Mansión sexta nos invita a imaginar el modesto conjunto de pinturas atesorado por un canónigo del Albaicín. Como cabía esperar, la evocación lírica de una serie de lienzos se vincula de manera connatural al entorno artístico de la Granada barroca.

Ciertamente, atendiendo a la historia del género desde la Edad de Plata latina, constituye un hecho poco habitual que el perfil del propietario de la mansión ornada de jardines o del poseedor de una singular colección de cuadros coincida con el del poeta que exalta dicha morada y sus colecciones artísticas. Como posibles paralelos, aunque no del todo exactos, podrían quizá aducirse los testimonios poéticos de Giovan Vincenzo Imperiale y Pietro Mellini. En el caso de Imperiale, como se ha indicado, dentro de una extensa sección de Lo Stato Rustico el aristocrático autor genovés acometía la descripción de la opulenta residencia de su familia, la Villa Imperiale en Sampierdarena, y de los vastos terrenos que la circundaban. Allí se haría eco de algunas pinturas que podían verse en la suntuosa morada. Salvando las debidas distancias, también podría aducirse otro notable paralelo que coincide parcialmente en el detalle del giro ecfrástico: los hoy no muy conocidos tercetos de la Relazione di molte pitture eccellenti di Casa Mellini. Allí, el noble romano Pietro Mellini (h. 1651-1694) aborda la descripción en verso de los cuadros que posee su familia desde hacía varias generaciones. Pietro envió el poema a su hermano, el cardenal Savo Mellini (1644-1701), que desempeñó las funciones de Nuncio papal ante la corte de Carlos II entre 1675 y $1685^{12}$. El menor

12 El texto forma parte de las Special Collections del Getty Research Institute. Desde el cinco de mayo de 2020 puede consultarse en red el manuscrito digitalizado de esta Relatione en endecasílabos, así como una cuidada transcripción del texto italiano junto a una traducción inglesa del poema. Véase todo ello en http://www. getty.edu/research/mellini/. Como apunta Murtha Baca en el estudio titulado "The 
de los Mellini pasa revista en 1681 a la exquisita colección de su familia, afincada en la capital de los estados pontificios desde hace varias centurias. El aristocrático poeta selecciona tan solo las piezas más deslumbrantes de la misma y, aun así, la descripción lírica que lleva a cabo incluye nada menos que noventa y cuatro cuadros y un dibujo, distribuidos en dos capitoli de 274 y 265 versos, respectivamente. Entre los maestros que podían verse en las salas del palacio Mellini se contaban Giorgione, Rafael, Dosso Dossi, Tintoretto, Paolo Veronese, Jacopo y Francesco Bassano, Palma il Vecchio, Tiziano, Lorenzo Lotto, Parmigianino, Correggio, Bronzino, Caravaggio, Giovanni Lanfranco, Domenichino, Annibale Carracci, el Cavalier d'Arpino, Paul Brill, Guido Reni, Paris Bordone, Valentin de Boulogne, Van Dyck y Velázquez ${ }^{13}$.

\section{A modo de preámbulo: la Introducción de Trillo y Figueroa}

Entre los personajes granadinos que frecuentaron la residencia de Soto de Rojas en el Albaicín se cuentan eruditos que gozaron de cierta ascendencia en la corte, como Martín Vázquez Siruela (1600-1664); poetas locales de indiscutible calidad, como Francisco de Trillo y Figueroa (h. 1618-h. 1680); jurisperitos como Bartolomé Ramón de Morales, abogado de la Real Chancillería y también nobles de alta cuna, como don Ínigo López de Mendoza y Vargas (†1656), VI marqués de Mondéjar, VIII conde de Tendilla, marqués consorte de Ayamonte y conde de Saltés, capitán

Manuscript and the Poem", la composición se articula como un díptico: "the poem itself is divided into two parts: the first, dated February 19, 1681, describes fiftythree works in the Mellini collection; the second, dated April 26 of the same year, contains forty-two works [...] The poem is written in terza rima [...]. The last stanza of the poem is a quatrain, with the rhyme scheme $A B A B$ ". Puede consultarse este trabajo en línea: conifer.rhizome.org/Getty/pietro-mellini-inventory-in-verse/ list/start-here/b1/20200505212806/http://www.getty.edu/research/mellini/essay/ manuscript-and-poem

13 Nuria Rodríguez Ortega, "Del inventario a las Galerías recreadas. Reflexiones en torno al manuscrito inédito Relatione delle pitture migliori di Casa Mellini (1681)", en Creación artística y mecenazgo en el desarrollo cultural del Mediterráneo en la Edad Moderna, eds. Rosario Camacho, Eduardo Asenjo y Belén Calderón, Málaga, Universidad de Málaga, 2011, pp. 257-278. 
general de las costas del Reino de Granada y alcaide de la Alhambra. En el marco suntuoso de las terrazas y paratas que conformaban los jardines del Carmen de los Mascarones los visitantes del recinto podían admirar el ingenio y la erudición que sustentaba la concepción de un espacio selecto, nacido para el deleite y la meditación, para el retiro y la fruición estética.

Soto de Rojas en las palabras liminares del volumen poético, dirigidas "Al que leyere", declaraba sin ambages que todo lector que desee adentrarse en el poema tendrá que advertir "las atenciones que pide su cultura”, ya que para aprehenderlo deberá identificar los "diversos sentidos sustanciales" del texto, apreciar "si las metáforas siguen sus pasos con proporción", mesurar la conveniencia y decoro de "los tropos, figuras y translaciones" empleadas, ser capaz de comprender las "voces o frases adoptivas" junto al "latino o el extranjero concepto", degustar las "imitaciones selectas" que no incurren jamás en "indicios de robos”... El receptor ideal del Paraíso cerrado no puede amilanarse ante los rasgos de la poética culta, ya que para admirar la esencia de una obra obscura cada lector debería disponer de una erudición semejante a la del escritor y su círculo. El jardín en verso permanece así "abierto" solo para una selecta minoría capaz de adentrarse en la compleja silva y apreciar su belleza. Con todo y con eso, el canónigo del Albaicín quiso incorporar al volumen una suerte de pequeña guía, la Introducción a los jardines del licenciado don Pedro Soto de Rojas, firmada por su amigo, el culto poeta don Francisco de Trillo y Figueroa. Con la ayuda de la misma, los lectores podrían hacerse una somera idea de la traza y disposición del carmen de los Mascarones, lo que les permitiría orientarse mejor por los vericuetos de la silva. Entre las páginas de dicha introducción, el autor de la Neapolisea explicitaba el origen e intención del poema descriptivo:

Habiendo, pues, adornado tanto [el canónigo Soto] la naturaleza y esta ciudad con la variedad de plantas, frutos, flores, fuentes, estatuas, pintura, artificios y adornos que en sus jardines, galerías y casa conocen todos, quiso - y con razón-que la memoria de tan hermoso edificio no falleciese con él, que también como los hombres mueren los edificios (según Luciano, diálogo IV de Aqueronte) y aun las familias, las ciudades, los imperios (según Veleyo Patérculo, libro II, donde "Ut appareat quemadmodum, urbium, imperiorumque, ita 
gentium") ${ }^{14}$. Por lo cual, y no por ambición o por soberbia, describió en el último tercio de su vida este florido poema que decanta sus jardines; obra (si mi juicio vale) no menos digna de aplauso que otra alguna y por la cual no merece detracciones ${ }^{15}$.

El deseo de hacer perenne el recuerdo de su propia mansión llevaba al poeta a componer una obra sumamente ambiciosa, que habría de redundar tanto en la gloria de su artífice como en la exaltación de Dios, en tanto señor de todo lo creado:

El intento de aqueste poema es dar noticia de lo que no pueden ver todos, dando vida por medio de la pluma a quien — faltando su dueño - no la tendrá como debe. El fin es para mayor alabanza de su primer artífice, a quien se debe el honor de lo criado. El modo, idea y argumento es el mismo que en su composición y ornato contiene el jardín y casa, sin hacer más que reducir a números su fábrica, porque es tan elegante que toda junta contiene un artificiosísimo poema compuesto de varios semblantes, fábulas, imitaciones y pensamientos, conceptos, figuras, exornación y adorno, a quien solo faltaba pronunciación que dijese: "Aquesto soy"16.

La “composición” y "ornato" del jardín real resulta "tan elegante" que viene a configurar materialmente "un artificiosísimo poema”, de manera que Soto de Rojas se limitó a dar voz a un paraje al que "solo faltaba pronunciación" ${ }^{17}$. Según establece el mismo Trillo, el poema se divide "en siete períodos, mansiones o descansos" al igual que "el objeto al que

14 La cita completa del pasaje de la Historia de Roma (libro II, XI, 3) recogía la siguiente reflexión sobre lo efímero: "Ut appareat quemadmodum, urbium, imperiorumque, ita gentium nunc florere fortunam, nunc senescere, nunc interire" ("Resulta patente que, al igual que las ciudades y los imperios, la fortuna de los linajes ya se hace pujante, ya languidece, ya se extingue"). Véase M. Velleius Paterculus cum notis Gerardi Vosii, Lugduni Batavorum, Ex Officina Elzeviriana, 1639, p. 25.

15 Soto de Rojas, op. cit., p. 82.

16 Ibidem, p. 84.

17 Resulta curiosa la coincidencia con una de las fórmulas cristalizadas que se vinculan desde época grecolatina a los poemas dedicados a retratos, cuya excelencia se pondera habitualmente mediante la frase "uox sola deest" ("solo le falta hablar", "solo le falta la voz"). 
mira”. En el recorrido de la visión que plantea el texto en prosa que antecede a la silva, se marcan por consiguiente las siete estaciones.

Por cuanto ahora nos interesa, el espacio donde se podían contemplar las pinturas se ubicaba en la penúltima terraza y, consiguientemente, puede leerse en la Mansión sexta del poema. El pasaje de la descripción de Francisco de Trillo y Figueroa reza así:

A este sitio salen dos ventanas de arco de un cuarto bajo, que tiene cuatro piezas corrientes con bóvedas o tabacados de blancos yesos; en ellas pinturas y láminas de nobles pinceles y algunas tallas de Mena y de los Garcías. Sálese de estas piezas hacia el poniente, a la sexta mansión ${ }^{18}$.

El entorno acotado en apenas tres líneas resulta de veras sucinto y proporciona una información demasiado magra. Al parecer, a la manera de una pequeña galería, el edificio podría definirse como un "cuarto bajo" en el que destacan "dos ventanas de arco", que constituirían la principal fuente de iluminación natural. Como si de una pequeña galería se tratara, la edificación se dividía a su vez en "cuatro piezas", que deben imaginarse interconectadas ("corrientes"). Entre el ornato principal de las mismas destacan los techos abovedados, en los que figuran algunos ornamentos. Por otro lado, en el pasaje destaca el uso de un arabismo dialectal (tabacado) que se vincula tanto al vocablo tabaque ("hueco entre dos paredes o entre cielo raso y techo") como al término — derivado del mismoatabacado ("hueco como tabaque, entre dos paneles, o entre cielo raso y

18 Tomo la cita de la editio princeps: Paraíso cerrado para muchos, jardines abiertos para pocos, Granada, Imprenta Real, 1652, fol. 14v. La edición cuidada por Antonio Gallego Morell presenta en este punto una errata llamativa, por salto de línea y repetición. El galimatías resultante no tiene, así pues, sentido: "A este sitio salen dos ventanas de nobles pinceles y algunas tallas de Mena y de los Garcías. [sic] con bóvedas o tabacados de blancos yesos, en ellas pinturas y láminas de nobles pinceles y algunas tallas de Mena y de los Garcías. Sálese de estas piezas hacia el poniente a la sexta mansión" (Obras de Pedro Soto de Rojas, Madrid, CSIC, 1950, p. 383). Por el contrario, el texto sí que figura reproducido correctamente en el tomo al cuidado de Aurora Egido: Paraiso cerrado para muchos, jardines abiertos para pocos. Los fragmentos de Adonis, Madrid, Cátedra, 1993, p. 90. 
techo"19). De las paredes de aquellas cuatro piezas pendían, pues, "pinturas y láminas" de algunos artistas de renombre ("nobles pinceles") y podían contemplarse a lo largo del recorrido también algunas esculturas religiosas, probablemente realizadas en madera policromada ("tallas de Mena y de los Garcías").

Como se infiere del citado parágrafo, las referencias que da Trillo resultan demasiado escuetas y se mueven en el difuso entorno de la alabanza genérica. Desde un punto de vista más detallado, sería interesante apreciar si el sintagma bimembre "pinturas y láminas" se corresponde bien a "cuadros" y "grabados" (o dibujos), bien a "lienzos" y "láminas" de cobre pintadas al óleo. Por supuesto, podría considerarse igualmente una simple hendíadis, referida globalmente a las "pinturas" que colgaban de aquellos muros. Por otra parte, de resultar atendible lo que afirma el autor de la Neapolisea, junto a la colección de cuadros también podía contemplarse allí una serie de “tallas de Mena y de los Garcías”. Dicho particular resulta digno de nota, ya que representa la única noticia sobre ese tipo de piezas en la colección artística de Soto de Rojas, puesto que entre los versos de la Sexta mansión del Paraíso cerrado no se mencionan tales esculturas.

Entre los modernos estudiosos que se han ocupado del poema, Rubén Pardo Lesta hablaba del gusto italiano que caracteriza a las mansiones quinta y sexta:

Se descendía a continuación a las mansiones quinta y sexta, las más italianizantes, centradas en motivos mitológicos grecolatinos y adornadas con numerosas esculturas y pinturas de artistas coetáneos al poeta: Alonso de Mena, Jerónimo y Miguel García, Alejandro Guevara, Ledesma, Bassano, Raxis y José de Ribera. Las dos mansiones se adornaban con una representación de Jasón y Medea junto al árbol del vellocino, a otro lado una representación del mito de Acteón junto a una fuente con una imagen de Neptuno y —en la mansión sexta - una fuente de gran altura coronada con una Venus que se apoya en una tortuga metálica, un estrado con Apolo y las Musas y otra fuente con una ninfa sobre un alto pedestal adornado de animales marinos ${ }^{20}$.

19 Federico Corriente, "Arabismos dialectales del iberorromance central", Estudios de dialectología norteafricana y andalusí, 3 (1998), pp. 65-124 (pp. 90 y 118).

20 Pardo Lesta, op. cit., p. 1023. 
Más allá de la importancia que cobran las figuras del mito en ambos entornos, quizá pueda sustentarse el vínculo con la concepción del jardín italiano mediante la presencia de una suerte de galería integrada en el mismo $^{21}$. Según se ha observado, esta edificación, presumiblemente, de modestas dimensiones, estaba destinada a albergar la colección de lienzos y esculturas, desempeńando así las funciones de espacio expositivo.

\title{
3. UNA GALERÍA GRANADINA DEL SIGLO XVII: TEMAS Y PROBLEMAS
}

Una vez acotado el vínculo de la écfrasis de pinturas con el género de las poesie di villa, tras haber individuado cómo pudo ser la pequeña galería ubicada en la sexta terraza del carmen, hemos de examinar en detalle el pasaje consagrado a la transposición de arte (vv. 720-823) ${ }^{22}$. Vaya por delante que en ese centenar largo de versos se localizan algunos fragmentos bastante oscuros, acaso deturpados por la presencia de erratas. Con el propósito de facilitar el acercamiento al mismo, resulta oportuno segmentarlo en diez pequeños bloques.

La presentación del paraje se refiere, lógicamente, a la edificación que Trillo había definido en su recargada prosa como un "cuarto bajo" que, a su vez, estaba dividido en "cuatro piezas corrientes":

\author{
De la mayor amenidad sitiada \\ cuatro piezas le asesta \\ que, en los combates de la ardiente siesta, \\ pavés aún no vencido \\ de infatigables rayos
}

21 Recuérdese cómo Trillo y Figueroa emplea (en plural) el término galería ya desde las prosas de la Introducción a los jardines del licenciado Pedro Soto de Rojas: "fuentes, estatuas, pintura, artificios y adornos que en sus jardines, galerías y casa" (editio princeps, fol. 8 v.).

22 No estará de más recordar cómo Soto de Rojas imitó a menudo en sus versos a Giovan Battista Marino, uno de los autores barrocos más proclives a mantener en su creación un rico diálogo con la pintura. Sobre la vinculación de la escritura lírica con las artes plásticas en la influyente obra del autor partenopeo puede verse ahora un magno monográfico coordinado por Emilio Russo, Patrizia Tosini y Andrea Zezza: Marino e l'Arte tra Cinque e Seicento, Roma, L'Erma di Bretschneider, 2021. 
de batir desmantelan sus desmayos.

Bóveda hermosa, de cristal cuajada, noble señal de Fidias elegante, (oro, azul, plata, gules) colorido contiene escudo. Respetó el olvido estrellas rojas y águila rapante fijas en él y —esferas de la Famasu nido en Valdeconcha, de alta rama ${ }^{23}$.

Desde el punto de vista elocutivo, esta primera sección se distingue por el empleo de la dilogía ingeniosa, con su característico "significar a dos luces". De forma aguda, toda una red de términos se adscribe al campo semántico de la guerra: "sitiada”, "piezas”, “asesta”, “combates”, "pavés”, "no vencido", "batir", "desmantelan". Ante los ojos de los lectores más perspicaces tiene así lugar una pugna entre dos elementos antagónicos: los rayos ardientes del sol frente a lo umbrío, el calor inclemente frente a la frescura del pequeño edificio. El concepto de fondo que late en estos versos es relativamente sencillo: el "cuarto bajo" está ubicado de forma que se mantiene fresco y resguardado incluso en la hora de la "ardiente siesta", convirtiéndose así en grato refugio frente a los "infatigables rayos" para todo aquel que recorre el jardín ${ }^{24}$.

Recuérdese cómo Trillo y Figueroa apuntaba que las "cuatro piezas corrientes" se ornaban con "bóvedas o tabacados", lo que va a concretar aún más el poeta al mencionar que en una de ellas campea el escudo de armas de los Soto y los Rojas: "[una] bóveda hermosa contiene [un] escudo colorido" de "oro", "azul”, "plata” y "gules"25. El blasón heráldico proclama

23 Soto de Rojas, op. cit., pp. 124-125.

24 Como generosamente me apunta Mercedes Blanco, pese a que el concepto de fondo esté relativamente claro, algunos detalles "de la sintaxis del fragmento no resultan muy nítidos".

25 Desde el mismo entorno de la dilogía, la frase "le asesta cuatro piezas" remite en una primera lectura al campo bélico ya indicado, puesto que el verbo "asestar" reviste la acepción de "dirigir un arma hacia el objeto que se quiere amenazar u ofender con ella" o "descargar contra algo o alguien un proyectil, un golpe de un arma". Ahora bien, en la dicción áurea el verbo habitualmente asumía también otro significado, ahora caído en desuso: "preparar", "tener pensado". La figura de la ninfa acuática que había comparecido en el verso 720 (la "Naya") y a la que rendía su devoción el locutor poético (“yo que a su culto mi atención consagro” v. 723) podría iden- 
como solar de sus ancestros el señorío de Valdeconcha, en Guadalajara. Según se lee en diversos testimonios desde finales del siglo XV, "el solar de Soto trae por armas un escudo de plata con un águila cuartelada de oro y de gules, orlado el escudo con ciertos candadicos abiertos, de sable" 26 . Por su parte, el emblema heráldico de los Rojas presenta en campo de oro cinco estrellas de azur. El poeta evoca así los principales constituyentes heráldicos de su "colorido escudo" (el "águila” rapante y las "estrellas") así como los colores del mismo ("oro", “azul”, "plata”, "gules”).

Identificado el espacio de la pequeña galería en cuatro salas, el lectorcaminante que recorre las mismas se halla ante el primer cuadro, que Soto va a pintar verbalmente entre los versos 739-747:
$\mathrm{Al}$ material actor o al instrumento de tantas variedades retrato ofrece en su ejercicio solo Guevara: de Alejandro acción y Apeles representó, cuando Átropos de acero golpe tiró el postrero. Quedó con vida el lienzo y los pinceles a mayores edades y a más noticias del opuesto polo ${ }^{27}$.

Presenta el pasaje dos dificultades, que afectan nada menos que a la identificación del artista (al que se nombra únicamente con el apellido "Guevara") y al reconocimiento del tema específico del lienzo ("de Alejandro acción y Apeles"). A la hora de determinar la identidad del pintor se ha apuntado la posibilidad de que se tratara de un artista de origen noble, vinculado a los círculos malagueńos y granadinos, Juan Nińo de Guevara

tificarse como antecedente del pronombre personal (mi devoción y culta atención "le asesta"). Por tanto, cabría interpretar el pasaje del modo siguiente: la cuidada organización del terreno en la sexta terraza pone a disposición de la bella ninfa un cuarto bajo, rodeado por el más ameno entorno. Dicha edificación se compone de "cuatro piezas" que durante las horas de mayor calor pueden servir para guarecerse del sol y disfrutar de la frescura y la sombra.

26 Borja del Rivero, "El águila a contracolores", Ascagen, 8 (2012), pp. 103-117 (p. 112).

27 Paraiso cerrado para muchos, jardines abiertos para pocos, Madrid, Cátedra, 1993, p. 125. 
(Madrid, 2 Febrero 1632-Málaga, 8 Diciembre 1698). Suele estimarse que Niño de Guevara había realizado su aprendizaje en la ciudad de Málaga junto al pintor hispano-flamenco Miguel Manrique. Se considera, además, que en 1648-1649 pudo haber completado su formación en la corte madrileńa junto al artista granadino Alonso Cano ${ }^{28}$.

Ciertamente, en lo temporal dicha identificación resulta de lo más problemática, ya que si la écfrasis de Soto se refiriera a un lienzo salido de la mano de Juan Niño de Guevara habría que fechar tal obra algo antes de 1651, toda vez que la aprobación del Paraíso se firmó el ocho de junio de ese mismo año. Por esa razón, siguiendo el razonamiento forzoso que marca tal hilo cronológico nos hallaríamos ante la mención de una pintura muy temprana del artista malagueño, un cuadro de historia que debió haber pintado cuando contaba apenas dieciocho o diecinueve años.

Si la identificación del autor resulta algo problemática, no lo es menos la especificación del asunto de la obra pictórica. En la editio princeps figura una glosa marginal: "Plutarcus. Quintus Curtius". Atendiendo a la prosificación del fragmento realizada por José Fernández Dougnac, el estudioso granadino se decanta claramente a favor de la hipótesis de un cuadro que refleje la escena de La muerte de Alejandro Magno:

Un cuadro de Guevara, exhibiendo el único y solitario ejercicio al que se dedicó este artista (la pintura) ofrece a Dios (material autor de tanta belleza) y al divino instrumento con el que realizó tantas variedades una acción de la vida de Alejandro Magno: Átropos (la muerte) armada de acero le da el último golpe, escena que en la Antigüedad representó Apeles. Este lienzo y sus pinceles han quedado, por tanto, con vida, desafiando a las edades superiores y a las noticias más importantes del polo opuesto ${ }^{29}$.

28 Tras el óbito de Miguel Manrique (en mayo de 1647) debió de producirse el traslado del joven a la corte, para continuar sus estudios. El marqués de Montebelo "lo encomendó [entonces] a la escuela de Alonso Cano, entonces seglar y vecino de Madrid, que después fue racionero de la Santa Iglesia de Granada, quien le acabó de perfeccionar en el arte de la pintura con tal superior excelencia que llegó a igualar, si no a aventajar, las pinturas de su maestro", según refiere Palomino (apud Agustín Clavijo García, Juan Niño de Guevara, pintor malagueño del siglo XVII, Málaga, Universidad de Málaga, 1998, p. 20).

29 Fernández Dougnac, op. cit., pp. 227-228. 
En la pintura barroca resulta muy rara la representación de la muerte del monarca macedonio en el lecho y, hasta donde alcanzan mis noticias, si bien Apeles realizó numerosos retratos en vida del soberano helenístico, no pintó cuadro alguno que representara la escena de su muerte:

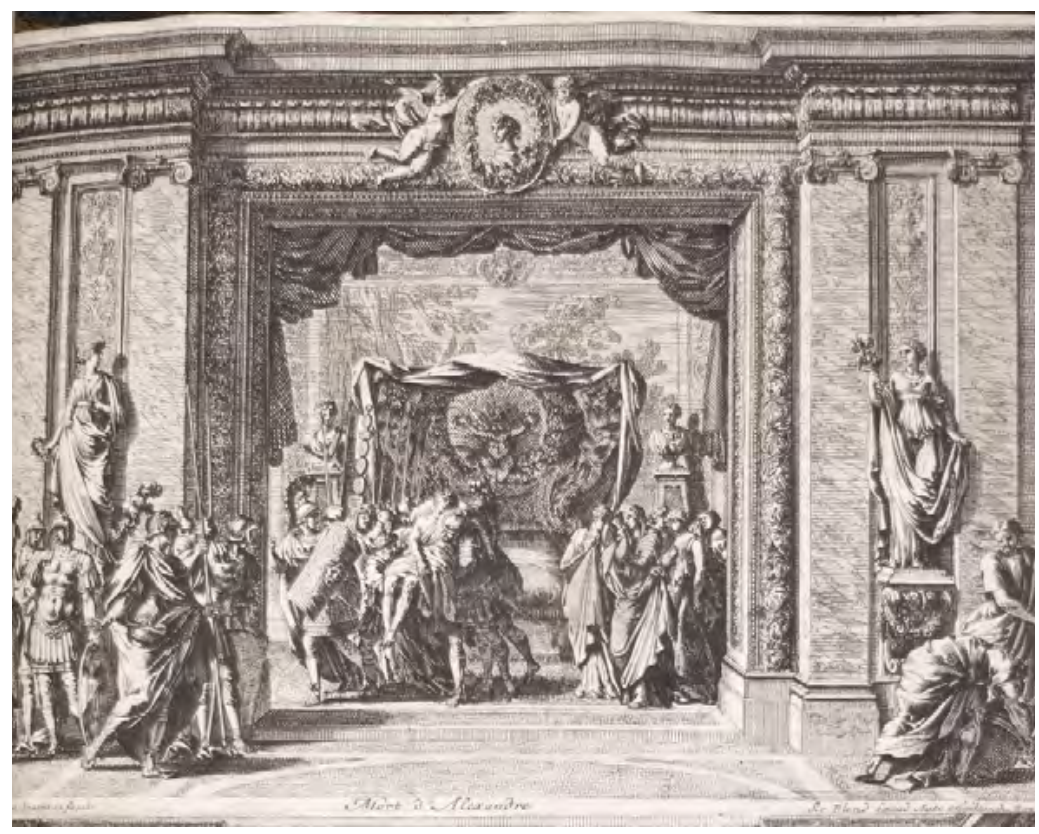

Figura 1. Jean Lepautre, La mort d'Alexandre.

La mención del renombrado artista griego suele asociarse, en cambio, con otro episodio de la vida de Alejandro Magno en el Siglo de Oro, ya que aparece tanto en poemas como en piezas dramáticas. Me refiero, claro está, a la conocida anécdota que daba cuenta de la liberalidad del rey, ya que este le cedió la bella Campaspe, su concubina, al "pintor de cámara" que estaba secretamente enamorado de ella ${ }^{30}$.

30 Bienvenido Morros, "Sentido y fuentes de la canción de Bocángel Al caso de Apeles en La lira de las Musas", Dicenda, 19 (2001), pp. 179-242; Natalia Fernández Rodríguez, "Apeles enamorado: la reflexión artística como clave del conflicto dramático en la Comedia Nueva”, e-Spania, 35 (2020), pp. 1-13. Puede consultarse el texto en red: https://journals.openedition.org/e-spania/33772?lang=en. 
Del género de la pintura de historia, referida a una escena del mundo grecolatino, Soto va a pasar a la evocación de un cuadro de tema paisajístico, puesto que el segundo lienzo remite a una modalidad concreta de este género. Se trata de un paisaje de marismas o parajes ribereños, en el que figura una escena de cetrería (vv. 748-759):
Por los países fatigar el viento
cuidadosa se ve la cetrería
ocupando los términos del día
y del aire en la pesca más plumosa
o caza de las ondas más mojada;
barquilla deleitosa,
con galas y hermosuras sumergida,
peso del alma y cargas de la vida,
se conoce ocupada,
insinuando a canes guedejudos
a aprisionar inoxias libertades
entre cańas conformes, entre nudos ${ }^{31}$.

A la altura de los versos 748-749 figura una glosa marginal en la que se lee escuetamente "Pintura". Poco después, a la altura de los versos 751-752, se ubica otro ladillo que reza "Pays" [sic]. Creo que la pareja de escolios podría verse como una suerte de hendíadis, ya que realmente apunta hacia el género de obra plástica descrita con ágiles pinceladas verbales en el fragmento: una pintura de paisaje en la que se contempla una escena de cetrería en un entorno acuático a la que asisten varias figuras, asistidos por canes de lanas que acuden a recoger las presas entre cañaverales o juncales.

La curiosidad de los lectores no queda del todo satisfecha con estos versos, ya que en ellos Soto de Rojas no menciona al autor del lienzo. A modo de hipótesis, podría pensarse que la obra respondiera acaso a alguno de los esquemas fijados por los maestros paisajistas de Flandes y Holanda en el siglo XVII. Para hacerse una somera idea de los mismos, pueden recordarse algunas piezas representativas de Joos de Momper, Philips Wouwerman, Philips Koninck o Roelof Jansz van Vries. El primer cuadro se atribuye al círculo de Joos de Momper (1564-1635):

31 Paraíso cerrado para muchos, jardines abiertos para pocos, Madrid, Cátedra, 1993, p. 126. 


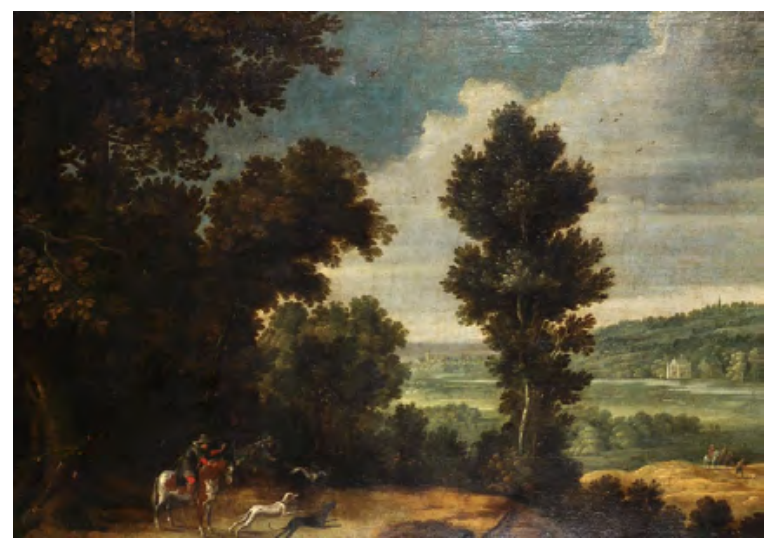

Figura 2. Joos de Momper, Paisaje con escena de cetrería

También pueden contemplarse escenas semejantes en otro tipo de pintura algo más tardía, difundida entre los círculos holandeses. Por ejemplo, hacia 1655 se data la Partida de cetrería entrando en un rio de Philips Wouwerman y taller. En este óleo la escena principal se dispone en primer plano: un "grupo de cazadores distinguidos llega por un estrecho camino a la orilla de un río poblado por multitud de figuras populares de jinetes, caminantes, bañistas y mendigos" 32 .

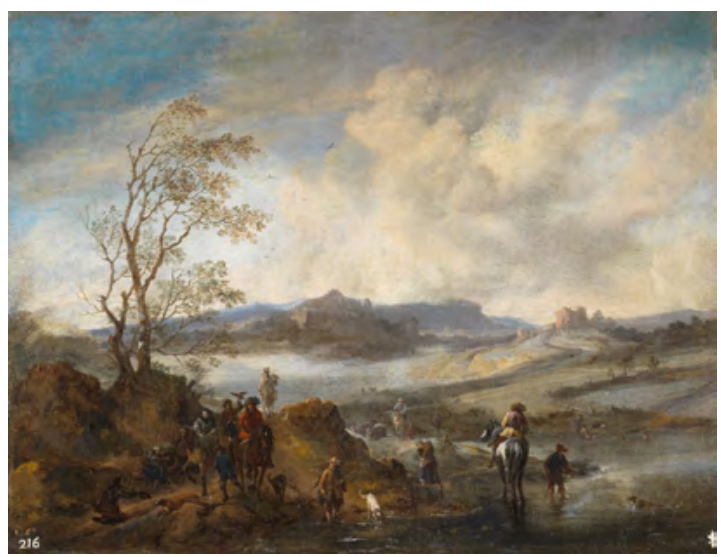

Philips Wouwerman y Taller, Partida de cetrería entrando en un rio (h. 1655-1658). Óleo sobre lienzo, 50 x $66 \mathrm{~cm}$. Madrid, Museo del Prado.

32 Teresa Posada Kubissa, Pintura holandesa en el Museo Nacional del Prado. Catálogo razonado, Madrid, Museo del Prado, 2009, p. 182. 
Durante las décadas posteriores, el artista Philips Koninck (1619-1688) realizó varios paisajes con escenas cinegéticas usando un tipo de composición muy similar.

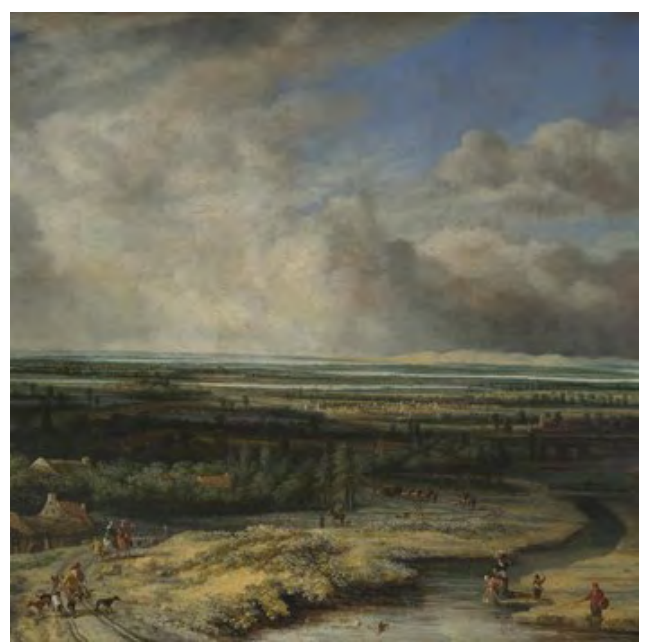

Figura 3. Philips Koninck, Paisaje con escena de cetreria (An extensive landscape with a hawking party) (h. 1670). Óleo sobre lienzo, 132,5 x 160,5 cm. National Gallery (Londres).

Los ejemplos podrían multiplicarse, aunque para evitar prolijidad nos limitaremos ahora a recordar un último lienzo de Roelof Jansz van Vries (Haarlem, 1631-Amsterdam, 1681).

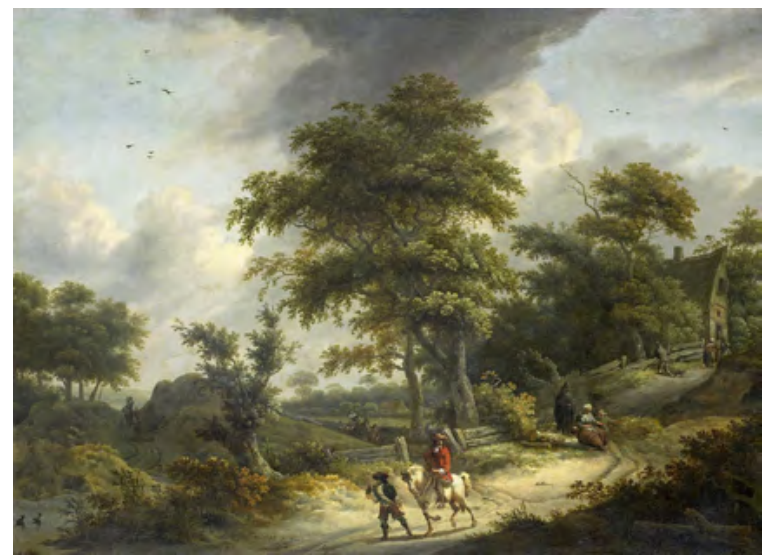

Figura 4. Roelof Jansz Van Vries, Landschap met valkenier (h. 1670).

Óleo sobre lienzo, 63 x 85 cm. Rijksmuseum (Amsterdam). 
Volviendo a la écfrasis del paisaje cetrero bosquejado por Soto de Rojas, si bien la autoría del lienzo queda en penumbra, así como la procedencia de la pintura, resultan bastante claras - desde el punto de vista de la imitatio- las huellas del modelo de la Soledad segunda en estos once versos ${ }^{33}$. En primer lugar, el uso de la hipálage doble se aplica a la identificación de la actividad cinegética con aves de presa en un entorno marismeńo o fluvial, con obvio trueque de atributos: la cetrería puede verse entonces como "la pesca más plumosa del aire" o "la caza de las ondas más mojada" ${ }^{4}$. Si en las Soledades el peregrino observaba la escena cetrera desde un "batel" (v. 707), en el lienzo se siguen los lances de las aves desde una "barquilla deleitosa" (v. 753) 35 . Los ocupantes de la pequeña embarcación indican a los perros de aguas a dónde se deben dirigir para localizar la pieza abatida: "insinuando a canes guedejudos / a aprisionar innoxias libertades / entre cañas conformes, entre nudos" (vv. 757-759). Ese mismo detalle se percibe en la obra maestra gongorina: "Can de lanas prolijo (que animoso / buzo será, bien de profunda ría, / bien de serena playa, / cuando la fulminada prisión caya / del neblí [...])" (vv. 799-803) ${ }^{36}$. Por lo que atañe al entorno acuático en el que crece una serie de plantas características, pueden cotejarse asimismo los versos de Soto y los gongorinos: "entre cañas conformes, entre nudos. / El rubio Pan siguió la ninfa bella / que hoy partida guarnece / sin verduras, sin flores, sin brotones" (vv. 760-763) / "Rebelde ninfa (humilde ahora caña) / las márgenes oculta / de una laguna breve" (vv. 831-833).

33 Ponce Cárdenas, "La imitación del discurso gongorino de la cetrería: primeras calas", pp. 171-194.

34 Aunque este tipo de modalidad cinegética no sea tan conocido hoy día, para entender el paisaje cetrero que Soto pinta aquí verbalmente debe tenerse en cuenta cómo, al ser abatidas las aves acuáticas (ánades, garzas, grullas, patos...) por las aves cetreras (neblí, baharí, azor...), tales presas caen en zonas húmedas de difícil acceso a causa de la abundancia de cańas y juncos.

35 Luis de Góngora, Soledades, ed. Robert Jammes, Madrid, Castalia, 1994, p. 521. Seguidamente espigo otras citas del poema, localizables en las pp. 545 y 551.

36 Con el empleo del verbo aprisionar quizá Soto esté recordando el uso del tecnicismo cetrero "prisión" por parte de Góngora y apuntando alusivamente al mismo, ya que aquella voz indicaba "en la caza es el ave o animal contra la cual se lanza el halcón: como las liebres, conejos, grullas, cigüeñas, ánsares bravas, garzas, avutardas y otras semejantes, que se prenden o en tierra o en agua o muy cerca de ellas por los azores o halcones" (Diccionario de Autoridades). 
Desde el punto de vista ecdótico, la mayor dificultad del pasaje proviene de un vocablo inusitado, que puede leerse en las ediciones modernas del poema escrito del modo siguiente: "hinojias". Los varios intentos de acotar el sentido de dicho término quedan lejos de esclarecer el asunto de manera definitiva. En primer lugar, Aurora Egido señalaba que "binojias puede referirse metafóricamente al 'hinojo marino', hierba de hojas carnosas y flores blancas que crece entre las rocas" ${ }^{37}$. Por su parte, José Fernández Dougnac seguía al pie de la letra el parecer de la académica, prosificando así el fragmento:

\begin{abstract}
Otra pintura muestra a una vigilante cetrería, ocupando el cielo al atardecer, cuyos halcones alcanzan tal celeridad en el vuelo que, por distintos territorios, parecen fatigar al mismo viento. Completa el cuadro una barquilla, sumergida con sus galas y hermosuras, que siempre serán peso del alma y cargas de la vida, cuyos ocupantes están atareados en la captura de aves (la pesca más plumosa en el aire) o en la captura de peces (la caza más mojada en las ondas), insinuando a canes peludos o de largas guedejas que husmeen por los alrededores y, por tanto, a aprisionar con sus patas las acuáticas libertades de las hierbas denominadas hinojos marinos, para así recoger algunas piezas, y a que estos se muevan entre las cañas bien proporcionadas de los cestos y entre los nudos de las redes que se encuentran sobre las hierbas ${ }^{38}$.
\end{abstract}

La mención de una planta del tenor del hinojo marino resulta algo extraña en el fragmento y plantea problemas, ahora bien una nueva propuesta permitiría aclarar ese pequeño misterio atendiendo al testimonio de la edición del siglo XVII, ya que por mera cuestión gráfica en este pasaje de la silva se ha ido transmitiendo y ampliando un curioso error. En efecto, la situación se aclara no poco cuando acudimos directamente al testimonio de la editio princeps, ya que Soto de Rojas había empleado un llamativo epíteto de origen latino: "inoxias libertades". De hecho, para ser

37 Paraíso cerrado para muchos, jardines abiertos para pocos, Madrid, Cátedra, 1993, p. 126 , nota 100.

38 El Paraíso comentado. Estudio, edición y versión en prosa del Paraíso cerrado de Pedro Soto de Rojas, Granada, Ediciones Antonio Ubago, 1992, pp. 228-229. La cursiva es mía. 
del todo precisos, el texto impreso en 1652 quizá incorporaba ya una levísima errata, puesto que se había suprimido en el calificativo antepuesto la nasal geminada: "innoxias libertades" > "inoxias libertades". A mediados del siglo XX, la transcripción de Antonio Gallego Morell en la edición del CSIC resulta exacta en este punto ("inoxias" p. 406) mientras que en las otras dos ediciones mencionadas (la de Cátedra y la de Ediciones Ubago), el error tipográfico originario llegaría a generar modificaciones innecesarias: la incorporación de una "h-" inicial, la sustitución de la " $\mathrm{x}$ " por la "j" 39 .

El adjetivo latino innoxius-a-um se aplica a todo aquello "que no hace daño", a lo "que no resulta nocivo", a un tipo de ser "inofensivo", "inocuo" y —en sentido lato- "inocente" o "libre de culpa". Los usos poéticos del mismo se verifican ya en la literatura de época augústea, puesto que aparecía en dos de las obras mayores de Virgilio (Eneida, Geórgicas). A partir del uso virgiliano, el epíteto fue empleado por autores de la Edad de Plata (Estacio) y, transcurridas varias centurias, por algunos de los grandes vates de la lírica neolatina (Poliziano ${ }^{40}$. Es decir, cuando Pedro Soto de Rojas se decidió a introducir en el léxico hispano del siglo

39 Se trata de las pp. 126 y 162 , respectivamente.

40 Virgilio empleaba ya el calificativo en el segundo libro de la Eneida (vv. 682-684): "Ecce leuis summo de uertice uisus Iuli / fundere lumen apex, tactuque innoxia mollis / lambere flamma comas et circum tempora pasci" ("una tenue lengua de fuego parecía despedir resplandores sobre la cabeza de Julo e iba lamiendo el cabello del niño con inocua llama y en torno a sus sienes se alimentaba”). Tomo la cita de Virgil, Eneid, ed. H. R. Fairclough, Cambridge/London, Harvard University Press, 2006, p. 362. También se localiza en las Geórgicas (III, 283): "Miscueruntque herbas et non innoxia verba" ("y con hierbas lo mezclaron y conjuros nada inocentes"). Cito el texto latino de Virgilio, Geórgicas, ed. Pedro Conde Parrado, Lima, Pontificia Universidad Católica del Perú, 2009, p. 140. Por su parte, Estacio aplicaba el adjetivo a la voz progenie en su conocida epopeya (Thebais, VIII, vv. 608-609): "miserique innoxia proles / Oedipodae" ("prole inocente del desdichado Edipo"). Sigo la edición cuidada por Giovanna Faranda Villa: Tebaide, Milano, B.U.R., 1998, II, p. 570. Téngase en cuenta, además, que el calificativo innoxia aparece recogido en diversos usos dentro de una de las obras más consultadas en el Renacimiento y el Barroco, el volumen de los Epitheta de Ravisio Textor. El erudito francés situaba, por ejemplo, el término como primer elemento referido a la paz, con cita de otro pasaje atribuido al mantuano (Aetna): "Tanta quies illi est quod pax innoxia rapti". Tomo la cita del Epithetorum Opus Absolutissimum, Venetiis, apud Marcum Antonium Zalterium, 1588, p. 530. 
XVII un término latino resonante y prestigioso, este contaba ya con un aura poética de dos milenios. Si en lugar de fijarnos exclusivamente en el calificativo, se desea poner el foco en el sintagma nominal completo (innoxias libertades), también puede espigarse algún que otro testimonio de una iunctura análoga (innoxia libertas). Por ejemplo, sirva como botón de muestra este pasaje de una conocida obra redactada en latín humanístico y difundida con éxito por toda Europa, el Satiricon de John Barclay: "Hos si tam mansuetum iudicium offendit, damnantque beneficium innoxiae libertatis" 41 .

A la luz de tales datos, es lícito pensar que Soto de Rojas aplica el sintagma "inoxias libertades" a las aves pequeñuelas que son presa de las aves cetreras. Dado que tales avecillas son 'inofensivas', pues no atacan al ser humano, e 'inocentes', pues por su simpleza caen en las trampas que les han tendido los cazadores o son abatidas por las asechanzas de halcones y azores, la "libertad" que las caracterizaba antes se puede tildar — por extensión o figuradamente - de "inoxia", con un uso translaticio del epíteto que debemos identificar como un ejemplo de latinismo llamativo ${ }^{42}$.

Si se observa el texto del Paraíso en su conjunto, en verdad el interés de Soto por la cetrería se aprecia ya desde el arranque mismo de la composición, puesto que en la sección consagrada a evocar la estampa de Adán y Eva en el Paraíso, rodeados de un sinfín de animales, el vate granadino se

41 Euphormionis Lusinini sive Ioannis Barclaii Satyricon partes quinque, Amstelodami, Ex Officina Elzeviriana, 1658, p. 250. No estará de más recordar cómo el término latino ya había aparecido, de hecho, en las letras hispánicas antes de que lo empleara Soto de Rojas. En el Quinientos, había usado el mismo epíteto latinizante fray Bartolomé de las Casas, Apologética historia sumaria, Madrid, Alianza, 1992, p. 1285: "Con todo esto, muncha y grande parte de la inocente vida, modestia humana e innoxia conversación y buenas costumbres y carencia de vicios de los súbditos dependía de la bondad y buena orden puesta, regimiento y gobernación de los buenos reyes y señores".

42 Recuérdese, además, cómo en el marco de los poemas descriptivos de palacios y jardines se localiza algún otro ejemplo similar de écfrasis, referida igualmente a pinturas de paisaje con escenas de caza con aves de presa. Me refiero a la transposición artística de diferentes cuadros ubicados en la residencia veraniega de los reyes de Dinamarca, tal como los reflejara poéticamente el conde Bernardino de Rebolledo en una de sus composiciones más logradas: Hirscholme, la segunda de las Selvas dánicas. Me he ocupado de dicho argumento en Ponce Cárdenas, "La imitación del discurso gongorino de la cetrería: primeras calas", pp. 181-188. 
recreaba en la evocación de un conjunto de aves, entre las cuales destacaban varias rapaces (Mansión primera, vv. 173-189):

Plumosa ofrece escuadra,

hija del agua y del calor del día:

cuál si el viento taladra

imperïal los rayos desafía

que turba escuadra de nocturnos vuelos;

la sierpe cautelosa cuál conduce

a su albergue piadoso;

uno despliega el cerco numeroso

que cien ojos contiene;

otro el pico y las garras le previene

al rapante enemigo

que baja de los cielos

en real cetrería

y aquel que escucha y por hablar porfía

aquí ostenta fiscal que, cuidadoso,

con vista recogida sobre acero

la fiera acusa y amenaza al ave $e^{43}$.

También aquí el poeta granadino enlaza con el modelo gongorino de las Soledades y evoca entre las aves que habitan el paraíso algunas especies a través de alusiones más o menos nítidas (el águila, el pavo real...) junto a otros elementos indistintos, como las aves acuáticas ("escuadra plumosa hija del agua"), los ominosos pájaros nocturnos ("turba escuadra de nocturnos vuelos"), un ave indefinida que ha cazado una serpiente y la lleva a su nido ("cuál conduce la sierpe cautelosa a su piadoso albergue") y quizá la pugna entre una garza y un halcón ("otro le previene el pico y las garras al enemigo rapante que baja de los cielos en real cetrería”). Probablemente la referencia a "aquel que escucha y por hablar porfía / aquí ostenta fiscal" remita asimismo al hipotexto cetrero de la Soledad segunda (v. 892 "el deforme fiscal de Proserpina”), referido al búho ${ }^{44}$.

43 Soto de Rojas, op. cit., pp. 102-103.

44 Góngora, Soledades, p. 565. La cláusula de Soto "el viento taladra" puede conectarse con la fórmula empleada por don Luis en los vv. 910-911 de la Soledad segunda: "Auxiliar taladra el aire luego / un duro sacre". 
Tras un lienzo de asunto histórico profano y un paisaje con una escena de cetrería, Soto de Rojas rememora en el siguiente pasaje una escena mitológica. Al parecer no se trataría ni de un lienzo, ni de una pintura al fresco que ornara el techo de una de las piezas abovedadas (vv. 760-763):
El rubio Pan siguió la ninfa bella
que hoy, partida, guarnece
sin verduras, sin flores, sin brotones
tres de cándidos yesos artesones ${ }^{45}$.

La alusión a la fábula de Pan y Siringa resulta muy clara y se asemeja levemente a otro pasaje gongorino de la Soledad segunda (vv. 831-833): "Rebelde ninfa (humilde ahora cańa) / las márgenes oculta / de una laguna breve" 46 . Los adornos de tipo vegetal podrían revestir la forma estilizada del junco, trazando acaso una orla de estuco mediante ese motivo vege$\operatorname{tal}^{47}$. Otro dato indirecto viene a iluminar algo este particular: el cuarto bajo estaba dividido en cuatro piezas y sabemos que en la bóveda de una de ellas figuraba como adorno el escudo heráldico de Soto de Rojas.

En la sucesión de géneros pictóricos que vamos apreciando al recorrer la pequeña pinacoteca, le llega después el turno al bodegón. Dentro de las distintas modalidades (florero, frutero, bodegón de loza, bodegón de viandas) que ofrecía en el siglo XVII la naturaleza muerta, Soto va a cantar las virtudes de una obra de Blas de Ledesma. Para ello dispondrá,

45 El epíteto "cándidos" puede considerarse un latinismo de sabor gongorino ("blancos"). La voz artesón designa un "elemento constructivo poligonal, cóncavo, moldurado y con adornos, que dispuesto en serie constituye el artesonado" (RAE). El sustantivo "brotón", hoy en desuso, califica el "vástago o renuevo que sale del árbol" (RAE).

46 Luis de Góngora, Soledades, ed. Robert Jammes, Madrid, Castalia, 1994, p. 551.

47 Quizá pueda descartarse la otra interpretación posible, algo más peregrina: que el ornamento de las tres bóvedas restantes estaría ocupado precisamente por la pintura de la historia mítica de la ninfa Siringe y el dios Pan, que quizá se extendería por los "tres artesones de cándidos yesos" ubicados en el techo del edificio. Recuérdese cómo en el léxico de la arquitectura la voz "artesón" designaba un "elemento constructivo poligonal, cóncavo, moldurado y con adornos, que dispuesto en serie constituye el artesonado" (RAE). Por otra parte, se entiende por artesonado "el techo, armadura o bóveda con artesones de madera, piedra u otros materiales y con forma de artesa invertida" (RAE). 
junto a la especificación de la tipología concreta ("sus fruteros”), una alusión a la renombrada escena del certamen entre los dos grandes pintores helenos (Zeuxis y Parrasio). Los versos rezan así (vv. 764-769):

Vitrubio en tanto aseo su elegancia
acusa de ignorancia,
viendo de Zeuxis el pincel facundo
que (aplaudido en los términos del mundo)
por mano de Ledesma en sus fruteros
vuelve a engañar los pájaros ligeros.

Frente al carácter más o menos brumoso de los artistas y obras precedentes, finalmente el canónigo del Albaicín parece moverse en el ámbito de lo concreto: un bodegón de frutas pintado por Blas de Ledesma, en el que acaso podría figurar también un pajarillo. En efecto, la actividad pictórica de Blas de Ledesma se vincula al foco andaluz desde sus orígenes, ya que aprobó el examen que le habilitaba como pintor en la ciudad de Málaga en $1587^{48}$. Su labor aparece bien documentada en varias ciudades del entorno meridional, como Granada y Jaén, a lo largo de las décadas siguientes, entre 1597 y $1617^{49}$. Quizá esa cercanía geográfica facilitara la adquisición de un lienzo de Blas de Ledesma por parte de Soto de Rojas. En torno a la cuestión del género, José Manuel Almansa recalca la identificación del artista con el género de la Naturaleza muerta:

La producción de Ledesma está centrada en la pintura de bodegones, de la que es un gran maestro. El catálogo elaborado por Ramón Torres enumeraba hasta ciento catorce pinturas, todas ellas de temática bodegonista, muchas de las cuales habían sido atribuidas a otros pintores como Blas de Prado, Van der Hamen, Sánchez Cotán, etc.

48 David García Cueto, "El examen de pintor de Blas de Ledesma en Málaga (1587)”, Archivo Español de Arte, XCII, 365 (2019), pp. 93-97.

49 En un documento fechado el nueve de octubre de 1618 la esposa del artista, doña Leonor de Cárdenas, aparece como viuda. Tal testimonio ha permitido fijar hacia ese año el óbito del pintor. Véase Benito Navarrete Prieto, "Integración de la pintura barroca granadina en el contexto cultural europeo", en Antigüedades y excelencias, eds. Ignacio Henares Cuéllar y Rafael López Guzmán, Sevilla, Junta de Andalucía, 2007, pp. 94-117 (p. 103). 
En muchos de estos bodegones, Ledesma incluyó grutescos, sin duda por influencia de Aquiles y Mayner ${ }^{50}$.

Véase, a título de ejemplo, un bodegón firmado por Blas de Ledesma en la ciudad de Granada y que se data estimativamente en torno a 1610. La obra responde a un esquema bastante simple: en el centro de la composición se dispone sobre un antepecho un cestillo de mimbre repleto de cerezas. En equilibrada simetría, a ambos lados del cesto, se pueden contemplar en un segundo plano varias especies florales (iris).

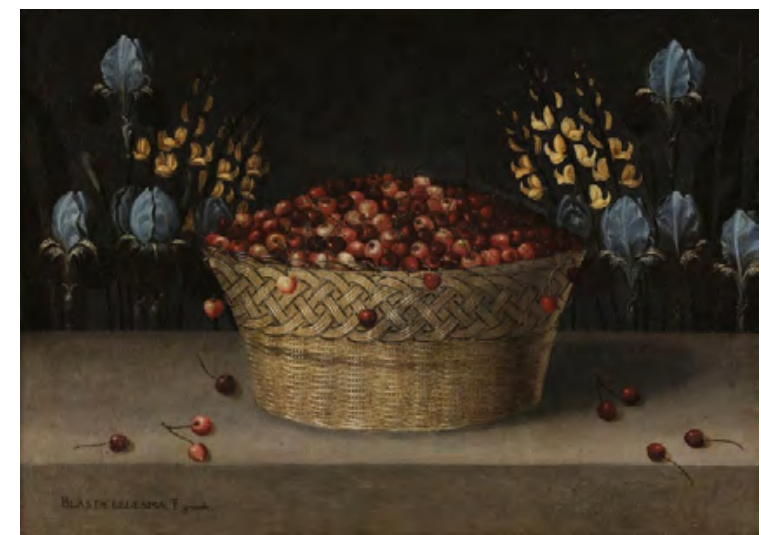

Blas de Ledesma, Still Life with Cherries, Lupin and Iris (h. 1610).

Óleo sobre lienzo. High Museum of Art (Atlanta, Georgia).

La presencia de las aves en varios Fruteros atribuidos a Ledesma permite conectar la tradición del género con la famosa anécdota anticuaria ${ }^{51}$.

50 Para las pocas claves que se poseen de la vida del artista, puede consultarse en línea la entrada que dedica José Manuel Almansa al pintor vinculado a los círculos granadinos en el Diccionario Biográfico de la Real Academia de la Historia http://dbe.rah. es/biografias/72129/blas-de-ledesma. Sobre la producción de naturalezas muertas, véanse Ramón Torres Martín, Blas de Ledesma y el bodegón español, Madrid, Lormo, 1978; y Peter Cherry, Arte y Naturaleza. El bodegón español en el Siglo de Oro, Madrid, Fundación de Apoyo a la Historia del Arte Hispánico, 1999. Remito también el reciente estudio de Clara González Fanjul, Araceli Gabaldón y Tamara Alba, "Bodegones atribuidos a Blas de Ledesma", Bienes culturales. Revista del Instituto del Patrimonio Cultural de España, 8 (2008), pp. 99-116.

51 Las aves que picotean la uva aparecían igualmente en algunos bodegones de Juan 


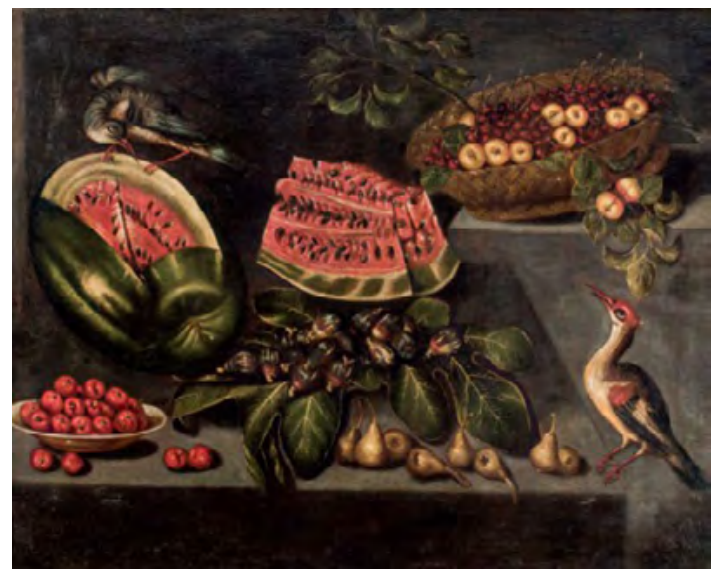

Figura 5. Blas de Ledesma, Bodegón con frutas y dos aves.

Óleo sobre lienzo, 75 x $93 \mathrm{~cm}$. Subastas Durán 2014.

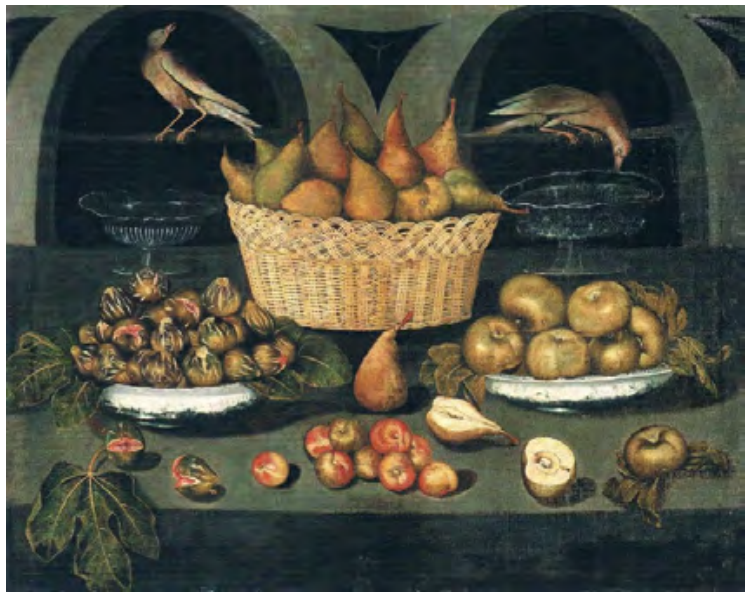

Figura 6. Blas de Ledesma, Bodegón con frutas y dos aves. Óleo sobre lienzo, 75 x 93 cm. Subastas Durán 2014.

La escena protagonizada por los dos artistas helenos, tal como la refiere Plinio el Viejo (Naturalis Historia, libro XXXV, 36, 10), se centra en la capacidad ilusionista de la pintura, que tiene la capacidad de engañar igualmente a las simples avecillas y a los creadores más conscientes del artificio:

Van der Hamen y León. Véase W. B. Jordan y Peter Cherry, Spanish Still Life from Velázquez to Goya, London, National Gallery, 1995, pp. 44-58. 
Descendisse hic in certamen cum Zeuxide traditur et, cum ille detulisset uuas pictas tanto successu, ut in scaenam aues aduolarent, ipse detulisse linteum pictum ita ueritate repraesentata, ut Zeuxis alitum iudicio tumens flagitaret tandem remoto linteo ostendi picturam atque intellecto errore concederet palmam ingenuo pudore, quoniam ipse uolucres fefellisset, Parrhasius autem se artificem ("Se cuenta que [Parrasio] se dispuso a entablar una competición con Zeuxis: este había presentado unos racimos pintados con tanto primor que los pájaros venían a picotearlos; mas [Parrasio] presentó una cortina pintada con tanto verismo que Zeuxis, muy orgulloso del fallo de los pájaros, pidió que corriese al fin la cortina para ver el cuadro. Después, reconociendo su error, concedió la palma con naturalidad y modestia, diciendo que él había conseguido engañar únicamente a los pájaros, mientras que Parrasio le había engañado a él mismo, a un artista”) ${ }^{52}$.

Merced al virtuosismo del pintor, el frutero de Blas de Ledesma conseguiría asumir las mismas virtudes de la antigua pintura griega, ya que el bodegón "vuelve a engañar los pájaros ligeros" (v. 769), tal como sucediera en la Grecia antigua con el cuadro o pinax creado por el "pincel facundo" de "Zeuxis" (v. 766).

Los dos cuadros siguientes eran, al parecer, de materia sacra. En efecto, entre los versos 770-783, Soto de Rojas aborda un asunto nebuloso, acaso vetero-testamentario, como el sacrificio de Isaac, junto a un episodio del Nuevo Testamento (el descanso en la huida a Egipto). Leamos ahora el pasaje:

De las negras borrascas del olvido, tormentas de la muerte procelosa, en dos tablas pequeñas al cielo dando agradecidas señas salen Basán y Alberto de este retrete de la Fama al puerto: aquel con el piloto que lleva por sufragio

52 Pline l'Ancien, Histoire Naturelle, ed. Jean-Michel Croisille, Paris, Les Belles Lettres, 2003, livre XXXV, p. 65. 
la nave al hombro en el mayor naufragio

(Isaac no socorrido, de amor sí en holocausto consumido

$y$, en sacrificio, de justicia roto);

este del mar con la mejor estrella

que del sol muestra a Egipto la luz bella.

La presentación de las dos pinturas asume desde el punto de vista elocutivo un sesgo ingenioso inequívoco. En efecto, mediante el empleo de una serie de voces náuticas, la evocación de ambos lienzos se asocia a la imagen de dos personajes salvados del "naufragio" del olvido y se disponen a consagrar sus "tablas" o exvotos en acción de gracias: "negras borrascas", "tormentas", "muerte procelosa”, "tablas", "dando agradecidas señas al cielo", "puerto”, “piloto”, "nave”, "naufragio”, “mejor estrella”.

El primer nombre hispanizado que aparece en el heptasílabo de Soto de Rojas ("salen Basán y Alberto") podría designar a cualquiera de los artistas pertenecientes a tan notable saga: Jacopo Bassano (h. 1510-1592), Francesco da Ponte Bassano (1549-1592) o Leandro da Ponte Bassano (1557-1622). Como es bien sabido, las piezas del taller de los Bassano gozaron de gran estima en Espańa desde el reinado de Felipe II hasta las postrimerías del siglo XVII y el "éxito" de las mismas "estribó en que fueron sinónimo de pintura moderna", celebrada como tal por "tratadistas y literatos" $"$.

53 Miguel Falomir Faus, Los Bassano en la España del Siglo de Oro, Madrid, Museo del Prado, 2001, p. 25. Baste recordar a modo de botón de muestra las menciones que Lope hace de ello, como bien recuerda Falomir en la citada monografía: "No eran de pincel moderno, / del Bassán o del Tiziano" (canto II del Isidro); "Esta pintura hermosa / que del pincel divino / en la tabla del mundo / miró desde su esfera luminosa / recién nacido sol, cuyo camino / apenas retrataba el mar profundo, / más digna del primero Protoplasto / fuera de ningún humano ingenio / aunque presuma de Bassán Teofrasto" (Isagoge a los Reales Estudios de la Compañía de Jesús); "Al tres veces heroico lusitano / gran duque de Berganza, aunque con tosco / pincel, que no de Bosco, / de Rubens o el Bassano / pinté aquel monte que en valor compite / con cuantos bañan Febo y Anfitrite" (La Vega del Parnaso). Sobre la relación del escritor madrileńo con los artistas de su tiempo y su conocimiento de la pintura, es obligado remitir a dos importantes ensayos: Javier Portús, Pintura y pensamiento en la España de Lope de Vega, Hondarribia, Nerea, 1999; y Antonio Sánchez Jiménez, El pincel y el Fénix: Pintura y Literatura en la obra de Lope de Vega Carpio, Madrid/Frankfurt, Iberoamericana/Vervuert, 2011. 
Como se indica en el pasaje, "Basán" alcanza el "puerto de la Fama” con un cuadro de pequeño formato donde se bosqueja una figura de "Isaac" sumamente llamativa, ya que aparece "consumido en holocausto de amor" y "roto de justicia en sacrificio". Los dos elementos ponderados contrastan con el rasgo iconográfico habitual: "no socorrido" del ángel. La enigmática configuración del pasaje ha despertado las fundadas sospechas de Mercedes Blanco, que con suma generosidad me ha hecho notar cómo en la exégesis sagrada uno de los varones identificados como prefiguración del Mesías en el Antiguo Testamento es el propio Isaac. De ser atendible tal hipótesis, el tema del cuadro podría ser Jesús camino del Calvario, cargando con la cruz. Las equivalencias que podrían establecerse entonces serían Cristo en tanto "piloto", la cruz como la "nave que lleva al hombro" y el luctuoso trance de la Pasión y Muerte del Redentor como "el mayor naufragio" que ha conocido el humano linaje.

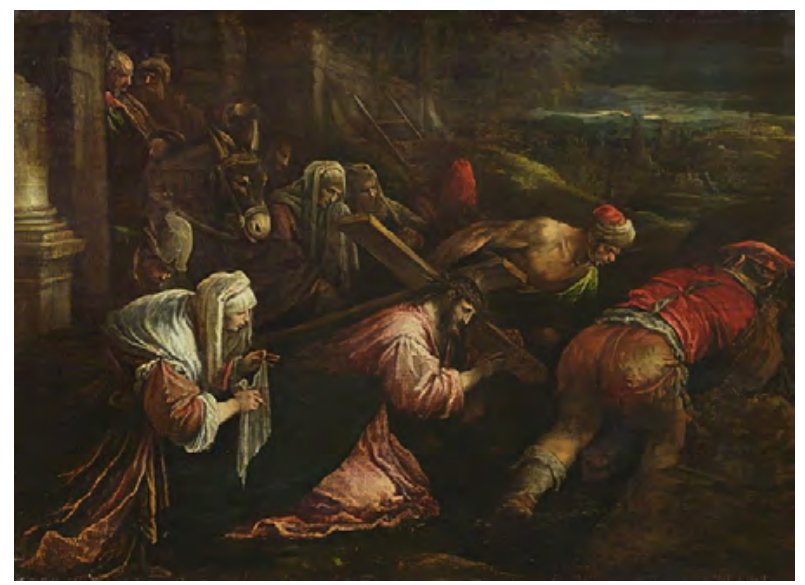

Jacopo Bassano, Cristo llevando la cruz, Óleo sobre tabla.

Musée de Beaux-Arts, Quimper.

La otra opción posible es que el lienzo aludido reproduzca sin más el instante que precede al "holocausto" que va a ofrecer Abraham, dispuesto a degollar a su hijo Isaac para honrar a Dios. A modo de recuerdo de algún ejemplo concreto, puede reproducirse aquí una pintura del cabeza de familia: Jacopo Bassano. Se trata de una obra de pequeño formato en la que aparece la mencionada escena bíblica: 


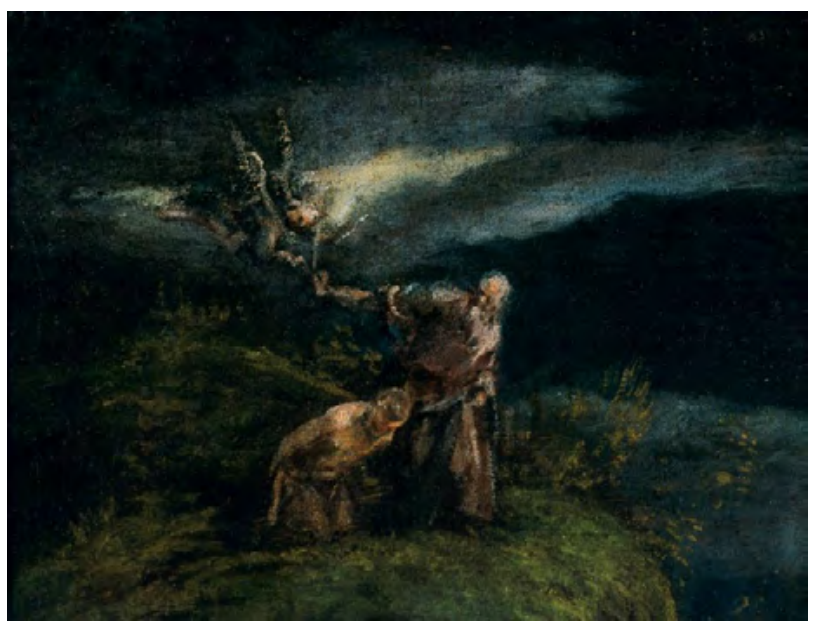

Figura 7. Jacopo Bassano, Sacrificio de Isaac (h. 1577).

Óleo sobre lienzo, 26,2 x 33,6 cm. Blanton Museum of Art Collections (Texas).

Por si ello fuera poco, a la dificultad de identificar el escurridizo asunto sacro y fijar la atribución de la pintura a cualquiera de los integrantes de la familia Bassano, vendría a sumarse otro detalle problemático: la costumbre de ponderar la excelsitud de un artista español atribuyéndole una identificación con la maniera de un maestro italiano. Así, Aurora Egido planteó en fecha temprana la posibilidad de que la mención de este "Bassán" por parte de Soto de Rojas no se refiriera directamente al artista véneto, sino al levantino Pedro de Orrente (Murcia, 1580-Valencia, 1645), conocido en la época como el "Bassano español", ya que parte de su formación se había desarrollado en Italia, precisamente en la bottega veneciana del miembro más joven de la saga de pintores, Leandro ${ }^{54}$. De hecho, a este "Bassán" español se debe una magnífica representación barroca de la escena bíblica, dotada de gran dinamismo y potencia:

54 Soto de Rojas, op. cit., p. 127, nota 102. 


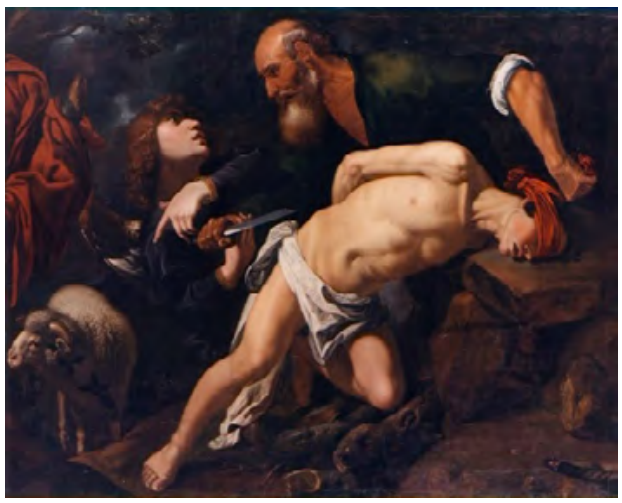

Figura 8. Pedro de Orrente, El sacrificio de Isaac (h. 1616).

Óleo sobre lienzo, 133,5 x 167 cm. Museo de Bellas Artes, Bilbao.

Conviene recordar asimismo cómo un pintor activo por aquellos años en el entorno granadino, Juan Leandro de la Fuente, "siguió el estilo de la familia véneta a través de la emulación del por entonces célebre Pedro de Orrente, famoso por crear desde el medio pictórico español un estilo propio basado en el arte de los Bassano" 55 .

En el pasaje de Soto referido a las dos pinturas de asunto sacro, quizá resulte lícito identificar la materia del segundo lienzo con un tema bastante desarrollado en el siglo XVII, el Descanso en la huida a Egipto. De nuevo, la identificación del maestro que pintó la "pequeña tabla” resulta algo espinosa, puesto que los versos se refieren a él únicamente como "Alberto". En verdad, no parece muy probable que figurara en la pinacoteca de un eclesiástico granadino de rango medio una obra del mayor artista del Renacimiento alemán, Albrecht Dürer (Alberto Durero) ${ }^{56}$. Quizá sea

55 David García Cueto, "El Anuncio a los pastores del taller de Leandro Bassano y las copias de los Bassano en Granada", en La pintura italiana en Granada. Artistas y coleccionistas, originales y copias, dir. David García Cueto, Granada, Universidad de Granada, 2019, pp. 339-344 (p. 343). El historiador del arte se refiere al pasaje del poema descriptivo en estos términos: "Aunque esta es la principal obra de los Bassano conservada desde antiguo en Granada [el Anuncio a los Pastores, de Leandro Bassano], queda constancia de la presencia de un Sacrificio de Isaac de "Basán" en el carmen del poeta Pedro Soto de Rojas en el Albaicín, siendo él mismo quien lo mencionó en su Paraíso cerrado para muchos" (ibidem, p. 341).

56 Sin embargo, quizá no deba descartarse (como bien me hace notar Mercedes Blanco) que también podría tratarse de una estampa y no de un cuadro. En ese caso, 
más lógico pensar en la autoría de un pintor de origen hispánico, acaso de la misma época que el poeta. Hace algunas décadas, Aurora Egido propuso la identificación con Bartolomé Alberto, "que pintó los frescos de la iglesia convento de Orihuela" 57 . A la luz de cuanto ahora se conoce sobre Bartomeu Albert cabe descartar dicha identificación por lo tardío de la cronología del artista ${ }^{58}$.

La serie ecfrástica que traza Soto de Rojas parece jugar constantemente con la alusión y elusión, tal como sucede en el fragmento siguiente. En efecto, desde los versos de este pasaje se va a ofrecer una encendida alabanza de José de Ribera (Játiva, 1591-Nápoles, 1652), aunque desafortunadamente se veda alguna pista clara sobre el asunto del lienzo (vv. 784-794):

Después ya que en la Italia generosa

lugar tomó el primero,

de la segunda pieza en el testero

al Justo dedicado

pone (y su nombre al bronce encomendado,

Jusepe de Ribera)

de su pincel en la estación postrera

a poca luz del sol y a mucha sombra;

mas con poco crepúsculo anochece

de metal rubio, en la mina batida

con blanda pluma y mezclas de colores.

La alabanza del Spagnoletto no está exenta de cierto orgullo nacional: la noble cuna de la pintura moderna (la "Italia generosa") reconoce al pintor

obligado es recordar cómo a Durero se debe un bellísimo grabado sobre La huida a Egipto.

57 Paraíso cerrado para muchos, jardines abiertos para pocos, Madrid, Cátedra, 1993, p. 127, n. 102.

58 La mayor parte de la obra pictórica conservada de Bartolomé Alberto se data en las décadas de 1680 y 1690. Se ha ocupado de este artista levantino Lorenzo Hernández Guardiola, "Bartolomé Albert y la decoración de la iglesia de Santo Domingo de Orihuela. Otras obras", en Pintura decorativa barroca en la provincia de Alicante. El último tercio del siglo XVII y primeros años del XVIII, Alicante, Instituto de Cultura Juan Gil Albert-Diputación de Alicante, 1990, pp. 99-149. 
levantino afincado en Nápoles el "lugar primero" entre todos los artistas de su tiempo ${ }^{59}$. Quizá sea lícito interpretar que la obra que poseyó Soto de Rojas fuera una pieza de madurez, como parece sugerir el endecasílabo 790 ("de su pincel en la estación postrera"). La vinculación del estilo de Ribera con el tenebrismo se enfatiza en los versos igualmente: "poca luz del sol", "mucha sombra", "poco crepúsculo" (vv. 791-792) ${ }^{60}$. Rafael Japón ha señalado en un trabajo reciente cómo "tres obras de José de Ribera" se "podían contemplar con seguridad" en el entorno granadino del "primer tercio del siglo XVII", dos de ellas pertenecieron a dońa Sancha de Mendoza y la tercera es la evocada por Soto de Rojas en su poema ${ }^{61}$. Afirma que en el Paraíso cerrado se "halaga dilatadamente [al Españoleto] siendo consciente de la ancianidad que alcanzaba el pintor por entonces", al tiempo que "describe un lienzo que representaría verosímilmente a un santo mártir”.

El siguiente pasaje plantea no pocas dificultades, con una referencia genérica a las "Sagradas Historias" y a lo que podría considerarse la imprecisa mención de un pintor de Flandes (vv. 795-806):

Las galas peregrinas de las flores

- majestad de las selvas venerables-,

las Sagradas Historias de la vida

escribe o representa

sobre más mucha matizada alfombra

bien Flamenco, ocupado

más que el móvil primero Tiempo ha dado,

obligando al pincel que viva y hable

siempre nuevo y estable.

59 Nicola Spinosa, Ribera, la obra completa, Madrid, Fundación Arte Hispánico, 2008.

60 La pintura de Ribera mereció el elogio poético de diversos autores, tanto en Italia como en Espańa. En la Hesperia Magna elogiaron con sus versos los lienzos del Spagnoletto autores como Girolamo Fontanella, Giuseppe Campanile y el jesuita Giovanni Michele Silo. Ha estudiado recientemente la proyección literaria del pintor levantino Lisandra Estévez, "The Spanish Zeuxis: Jusepe de Ribera’s Image in Baroque and Modern Poetry and Plays", Paragone: Past and Present, 1 (2017), pp. 29-63 (sobre Soto de Rojas, véanse especialmente las pp. 40-41).

61 Rafael Japón, “Caravaggio, Ribera y la pintura naturalista italiana en Granada”, en La pintura italiana en Granada, pp. 169-212 (p. 188). 
Aunque atezada, eternidad lustrosa vincula a pincel tanto rico el ébano santo.

Los elementos que se esbozan aquí son muy magros: la "matizada alfombra" cubierta por "las galas peregrinas de las flores", la suntuosa "majestad de las selvas venerables" parecen remitir a un entorno idílico que se caracteriza indudablemente por una vegetación feraz. Al mencionar "las Sagradas Historias de la vida" quizá no sea descabellado relacionar el tema de la pintura con una escena propia del Jardín del Edén. De hecho, podría intuirse quizá una vaga relación con la tipología de los cuadros del artista flamenco Brueghel de Velours dedicados al Paraíso terrenal.

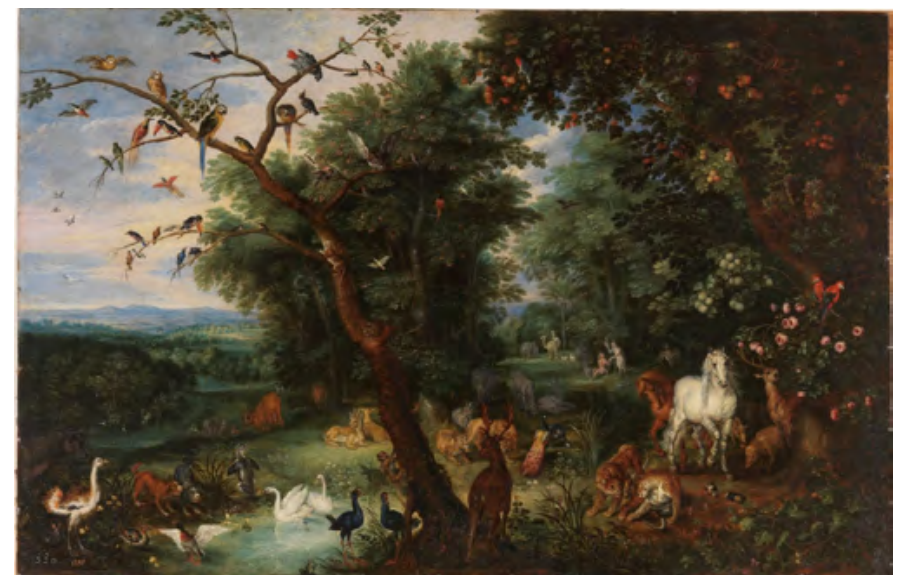

Figura 9. Jan Brueghel el Joven, El Paraíso terrenal, h. 1626.

Óleo sobre lámina de cobre, 57 x $88 \mathrm{~cm}$. Museo del Prado, Madrid.

Por otro lado, si atendemos al testimonio del escolio que figura en el ladillo ("Guarniciones de ébano"), los tres versos que cierran este pasaje pueden acaso apuntar a un detalle de la cultura material del tiempo: la madera preciosa de la que estaba hecho el marco del cuadro ("ébano") o quizá el coperchio o 'cubierta' que lo protegía.

Coronando la serie, el último artista — esta vez nombrado directamente- pertenece a un linaje de pintores y escultores oriundo de Cerdeña y afincado en Andalucía desde el siglo XVI. Se trata de una figura representativa de la escuela granadina (vv. 807-811): 
En vida más perfeta

que tuvo indiano siendo anacoreta,

Raxis un lienzo anima

con la paciencia del Cordero y suya;

oribe, al rey de fieras embravece ${ }^{62}$.

Entre los diferentes miembros de la familia Raxis dedicados a la creación artística, varios ostentaron el mismo patronímico ${ }^{63}$. Atendiendo a la cronología, entre las diversas posibilidades de identificación que así se plantean, parece probable que el pintor mencionado por Soto de Rojas fuera bien Pedro de Raxis el Mozo (Alcalá la Real [Jaén], 1555-Granada, 5 de junio de 1626), bien el menor de sus vástagos, Pedro de Raxis (1599$1640)^{64}$.

62 La prosificación de Fernández Dougnac, op. cit., pp. 231-232, reza así: "El pincel de Raxis anima otro lienzo realizado con la paciencia del cordero y la suya propia: como si se tratase de un orífice o artesano que trabaja el oro, por medio de dorados tonos embravece a un león, rey de las fieras, que luce hermosamente pintado".

63 Para la vida del artista, véase la entrada que dedica Lázaro Gila Medina a "Pedro de Raxis" en el Diccionario Biográfico de la Real Academia de la Historia, disponible en red: http://dbe.rah.es/biografias/27424/pedro-raxis. Del mismo estudioso pueden consultarse "En torno a los Raxis Sardo: Pedro de Raxis y Pablo de Rojas en la segunda mitad del siglo XVI", Atrio, 4 (1992), pp. 35-48; y "Aproximación a la vida y obra del pintor y estofador alcalaíno-granadino Pedro Raxis", Archivo Español de Arte, LXXVI, 304 (2003), pp. 389-406. Más reciente es la aproximación de José Manuel Almansa, "Pedro de Raxis y la pintura mural del Renacimiento en el Reino de Jaén", en Miradas a la pintura de época moderna entre España e Italia. Nuevas perspectivas, nuevas aportaciones, eds. Ximo Company, Iván Rega e Isidro Puig, Lleida, Universitat de Lleida, 2017, pp. 263-279; y Aldo Pillittu, "Per l'identificazione dei pittori Luis Machuca, Pedro Raxis e Miguel Raxis. Un itinerario fra l'Andalusia, Roma e la Sardegna”, en ibidem, pp. 281-295. Sobre el escultor Pablo de Rojas, hermano de Pedro de Raxis, véanse Francisco Martín y Francisco Rosales, Pablo de Rojas (1549-1613), escultor de imaginería, maestro de Martínez Montañés, Alcalá la Real, Ayuntamiento de Alcalá la Real, 2000; y Juan Jesús López Guadalupe, "Pablo de Rojas, encrucijada de las escuelas andaluzas", en La escultura del Primer Naturalismo en Andalucía e Hispanoamérica (1580-1625), ed. Lázaro Gila Medina, Madrid, Arco Libros, 2010, pp. 137-174.

64 Lázaro Gila Medina, "Pedro Raxis, singular miembro de la familia Raxis Sardo: vida, obra y descendencia artística”, en La pintura italiana en Granada, pp. 139168, escribe: "Pedro Raxis, cultivador con éxito de los más variados géneros y técnicas pictóricas, sobresaliendo como estofador y últimamente muy valorado como 


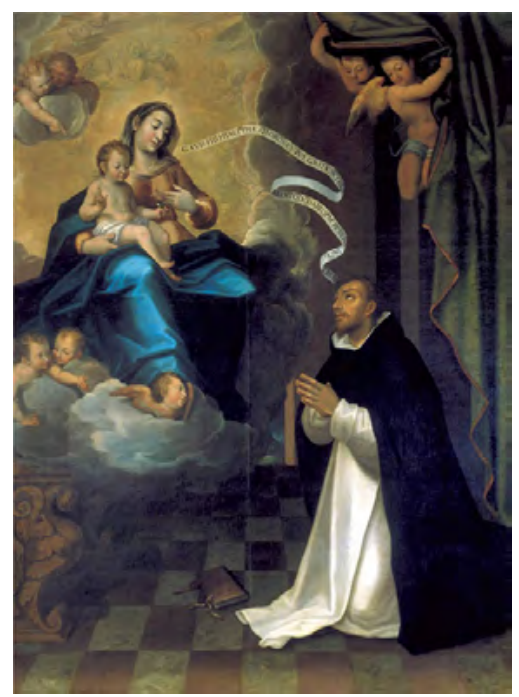

Figura 10. Pedro de Raxis, Aparición de la Virgen a San Jacinto de Polonia, óleo sobre lienzo, 291 x $210 \mathrm{~cm}$. Museo de Bellas Artes, Granada.

Padre e hijo destacaron como pintores, estofadores, doradores y muralistas, lo que justifica que el poeta exalte la capacidad del artista como "oribe" u "orífice", es decir el "artífice que trabaja con [pan de] oro" ${ }^{65}$. De hecho, Pedro de Raxis el Mozo "doraría y estofaría los armarios-relicarios de la Capilla Real” de la catedral de Granada en 1631. Entre la obra conservada de este artista cabría mencionar la Aparición del Niño Jesús a San

muralista, fue el creador de un complejo taller en Granada, activo entre 1575 y 1626, donde se formaron varios discípulos, como sus tres hijos, Felipe (1586-post 1626), Bartolomé (1592-1647) y Pedro (1599-1640)” (p. 139).

65 En su imprescindible Arte de la pintura, antigüedad y grandezas, Sevilla, Simón Faxardo, 1649, p. 360, el propio Francisco Pacheco había elogiado el talento de un Pedro de Raxis en aquel entorno granadino que puede enorgullecerse como legítimo heredero de la lección de Julio de Aquilis y Alejandro Mayner. El artista y teórico sevillano afirmaba: "De aquí pienso yo que se enriquecieron Julio y Alejandro, los cuales valientes hombres vinieron de Italia a pintar las casas de Cobos, secretario del Emperador en la ciudad de Úbeda, y de allí a la Casa Real del Alhambra en Granada (en una y otra parte a temple y fresco), la cual pintura ha sido la que ha dado la buena luz que hoy se tiene y de donde se han aprovechado todos los grandes ingenios españoles. De aquí Pedro Raxis, Antonio Mohedano, Blas de Ledesma y otros muchos, que han sido aventajados en esta parte”. 
Juan de Dios en Gaucin (Catedral de Granada) y el Martirio de San Bartolomé (iglesia de Nuestra Señora de la Aurora y San Miguel, Granada).

Tal como viene sucediendo con otros elementos de la serie ecfrástica, el pasaje del Paraíso cerrado resulta algo críptico a la hora de identificar el asunto del cuadro de Raxis. Los tres elementos esbozados ("indiano siendo anacoreta", "paciencia del cordero", "rey de fieras") parecen apuntar hacia algún tipo nada claro de escena sacra con la figura de un ermitaño y quizá un león.

Si el arranque del pasaje se abría con la mención de la galería o "cuarto bajo" de pinturas, el cierre de este apartado del Paraíso se va a coronar con el uso de una iunctura tan significativa como "los cultos umbrales del Museo". El espacio donde se exhibe la pequeña colección de cuadros y esculturas se erige así en un espacio consagrado a las musas, un "dulce albergue" rodeado de flores aromáticas y ornado con pinturas murales — "frisos" y "guarniciones" - de color diverso (vv. 812-823):
Pintura fresca la hermosura crece
debajo de los frisos,
guarniciones azules y oros lisos.
Vecina, pues, comunicarse intenta
mansión que (ya penúltima) se arrima
a los cultos umbrales del museo,
donde el mejor de su verdor empleo
ofrezca o restituya
(en jazmines, siringas y azahares,
del dulce albergue venerados lares)
- puesto que se las debe-
víctimas aromáticas de nieve ${ }^{66}$.

La técnica empleada en el último ornamento aludido se explicita al comienzo: "pintura fresca" o 'pintura al fresco'. Soto de Rojas acota así un tipo de decoración parietal que se ofrecería ante los ojos del visitante en elaborados "frisos" y en "guarniciones", alternándose diferentes tonalidades ("azules y oros lisos").

66 La voz "friso" designa aquí la "faja más o menos ancha que suele pintarse en la parte inferior de las paredes, de diverso color que estas. También puede ser de seda, estera de junco, papel pintado, azulejos, mármol" (RAE). 


\section{Pintura y Poesía: la misteriosa colección de un Canónigo Del Albaicín}

\section{Desde el punto de vista cultural, el fragmento del Paraiso cerrado de Soto} que se identifica como una serie ecfrástica presenta no poco interés ya que no solo configura una pinacoteca verbal sino que da noticia sobre el "pequeño coleccionismo" de pintura en la Andalucía barroca ${ }^{67}$. Sin duda, tanto el medio urbano como la pertenencia al estamento eclesial jugaron una baza importante en ese ámbito, según señalara Ana María Gómez Román ${ }^{68}$. Ciertamente, aunque parezca una obviedad insistir en ello, ese tipo de coleccionismo a escala reducida no admite parangón con el ejercido por el monarca o por los miembros de la alta nobleza, ya que los medios al alcance de aquel tipo de propietarios resultaban mucho más modestos. Con todo, en el grupo de aficionados al arte de la pintura compuesto por individuos de rango medio (caballeros del patriciado urbano, mercaderes enriquecidos, sacerdotes del clero secular) se percibe

67 Para el concepto de "pinacoteca verbal” permítase remitir a Jesús Ponce Cárdenas, Écfrasis: visión y escritura, Madrid, Fragua, 2014, pp. 25-38.

68 "A lo largo del siglo XVII los eclesiásticos fueron, junto con el estamento nobiliario y la monarquía, los grandes mecenas de las artes. A la par, durante esa centuria fueron adquiriendo una considerable presencia las galerías móviles de pintura de manera que las obras de arte se compraban, vendían, o heredaban, pero también se especulaba con ellas hasta el punto de surgir una abultada clientela con opinión propia en cuestiones artísticas. En la ciudad de Granada fue fundamental el papel que desempeñaron algunos eclesiásticos quienes movidos por rasgos de generosidad y piedad se afanaron de manera muy especial bien en completar la ornamentación de determinados espacios religiosos o bien en el adorno de ámbitos de carácter privado, auspiciando así el trabajo de ciertos artistas [...]. Fue así como un considerable número de pinturas y esculturas invadieron aquellos ámbitos señalados por estos promotores y clientes para su exhibición. A todo ello, un preciso grupo generó una tendencia acumulativa de obras de una cierta calidad artística, siendo quizá los arzobispos y canónigos quienes mostraron un mayor interés por esta práctica. Además, si analizamos en profundidad el prototipo de coleccionista que solía darse en esta ciudad observamos que, en su inmensa mayoría, eran individuos con un gusto encaminado al atesoramiento de obras de carácter religioso y devocional en detrimento de otros géneros, aunque hay que reconocer que también los hubo con inclinaciones más amplias y selectas" (Ana María Gómez Román, "La colección artística del canónigo Francisco Ruiz Noble y la serie de La Vida de José de Antonio del Castillo", Archivo Español de Arte, XC, 359 (2017), pp. 229-242 (pp. 229-230)). 
nítidamente el gusto de la época por géneros como la naturaleza muerta, el paisaje (flamenco u holandés), la pintura de historia (en su modalidad sacra, especialmente)... A lo largo de estos últimos años, se han realizado interesantes estudios sobre las colecciones privadas de algunos clérigos en diferentes ámbitos urbanos ${ }^{69}$. Por espigar algún ejemplo relevante, el caso del doctor Antonio de Riaño y Viedma, párroco de la madrileńa iglesia de San Miguel, fue objeto de un demorado análisis del llorado Trevor J. Dadson. En el testamento de este eclesiástico —otorgado en 1659el listado de las pinturas que poseyó alcanza una cifra nada desdeñable: trescientos lienzos ${ }^{70}$. Desde una cronología algo posterior, ya en las postrimerías del siglo, también reviste algún interés la figura del canónigo granadino Francisco Ruiz Noble, en cuyo testamento de 1694 se conserva noticia de los lienzos que atesoró en su domicilio ${ }^{71}$.

Sin duda, el elenco de cuadros que aparece en la silva de Soto de Rojas no presenta el mismo grado de fiabilidad que un inventario de bienes en un testamento, un documento de compra-venta refrendado ante notario o el listado de una almoneda. De hecho, como se ha visto, la identificación de algunos pintores resulta no poco problemática, por razones diversas. Con todo, no puede desdeñarse la información aportada por este pequeño ciclo de transposiciones artísticas. Al considerarlo en su conjunto, la hipótesis más plausible invita a pensar que en la pequeña galería del canónigo del Albaicín figuraron quizá pinturas de Juan Niño de Guevara, Blas de Ledesma, acaso uno de los Bassano, Jusepe de Ribera, un innominado pintor flamenco y Pedro de Raxis. Siguiendo el orden del poema, se podría esquematizar así el contenido de aquella curiosa pinacoteca ubicada en la sexta mansión:

1. Tema histórico profano (un episodio de la Vida de Alejandro, ¿Juan Niño de Guevara?)

69 Como aproximación general, puede verse el apartado que María Jesús Muñoz González consagra a la "Clientela eclesiástica" en su conocido ensayo sobre El mercado español de pinturas en el siglo XVII, Madrid, Fundación Caja Madrid-Fundación Arte Hispánico, 2008, pp. 66-86.

70 Trevor J. Dadson, "El coleccionismo particular en el siglo XVII: los cuadros y los libros del doctor Antonio de Riańo y Viedma, cura de la iglesia parroquial de San Miguel”, Hispania Sacra, L, 101 (1998), pp. 175-222.

71 Véase Gómez Román, op. cit. 
2. Paisaje ribereño con escena de cetrería (autor ignoto)

3. Bodegón de frutas, Blas de Ledesma

4. Un lienzo de tema religioso (¿El sacrificio de Isaac?, ¿Cristo camino de la cruz?), acaso atribuible a uno de los Bassano

5. Una obra de tema sacro neo-testamentario (Descanso en la huida a Egipto, ¿Bartolomé Albert?, ¿una estampa de Alberto Durero?)

6. José de Ribera, pintura de tema desconocido.

7. ¿La creación del mundo? ¿El Paraíso? Cuadro flamenco, al estilo de Jan Brueghel el Joven (Brueghel de Velours)

8. ¿Un Anacoreta con una figura de animal en torno? Pedro de Raxis

Al hacer un balance estricto de la hipótesis esbozada a partir de este elenco, un lector interesado compartirá sin duda la perplejidad que en primer término asume el propio estudioso: las dudas que afectan a la temática y a la posible autoría de las ocho piezas se antojan — hasta el momentoirresolubles. A excepción de la naturaleza muerta de Ledesma, cuando se observa de cerca el texto de las evocaciones ecfrásticas del Paraíso cerrado cada imagen plantea un enigma. En verdad, la única esperanza para esclarecer un conjunto de dudas tan amplio sería el inesperado hallazgo de un inventario de bienes, un documento de compra-venta o algún otro tipo de documento notarial. Mientras ello no ocurra, todo crítico estará condenado a moverse en las brumas de la especulación.

Desde el marco huidizo y modesto de la hipótesis, podría decirse que la colección de Soto de Rojas acaso destacara por su diversidad, ya que acoge muestras de casi todos los géneros: naturaleza muerta (frutero), paisaje con escena de caza (cetrería), pintura profana (una escena de la vida de Alejandro) y pintura religiosa (sacrificio de Isaac o Cristo camino del Gólgota, descanso en la huida a Egipto, el jardín del Edén, escena con un anacoreta). Entre los artistas citados, cobran especial relevancia los maestros vinculados a los círculos granadinos: Blas de Ledesma y Pedro de Raxis.

El Carmen de los Mascarones, ubicado en el Albaicín, servía de cincelado joyel a "la naturaleza y [a la] ciudad [de Granada] con la variedad de plantas, frutos, flores, fuentes, estatuas, pintura, artificios y adornos que [ostenta] en sus jardines, galerías y casa”, tal como refería Trillo en 1652. Por los mismos años aproximadamente, en el entorno único del bello paraje granadino, se erigieron otras moradas suntuosas en las que podían 
admirarse ciclos pictóricos sumamente cuidados, como la Casa-Palacio de Santa Inés, donde figuraba un conjunto de frescos que muestra el influjo de las pinturas romanas de la Galleria Farnese, realizadas por Annibale Carracci $^{72}$. El estudio en paralelo de composiciones líricas, cuadros y frescos permitirá en lo sucesivo alcanzar un conocimiento más profundo del diálogo que mantuvieron las Artes Hermanas —Pintura y Poesía- en el siglo XVII.

72 Rafael Japón y David García Cueto, "Mitología y poesía en las pinturas murales de la Casa-Palacio de Santa Inés: la estela de Rafael y los Carracci en Granada", en La pintura italiana en Granada, pp. 255-286. 